\section{A Amazônia imaginada nos memoriais enviados ao Consejo de Indias no século XVII}

\author{
Francismar Alex Lopes de \\ Carvalho [1]
}

Artigo recebido em 02 de novembro de 2016 e aprovado para publicação em 17 de janeiro de 2017.

[1]Departamento de História da Universidade do Estado do Rio de Janeiro - Rio de Janeiro - Brasil.

E-mail: francismardecarvalho@gmail.com
Resumo: Por todo o século XVII, colonos e missionários exploraram assiduamente as terras baixas amazônicas, localizadas a leste do vice-reinado do Peru. Nos memoriais que enviaram ao Consejo de Indias, em que solicitavam mercês, apresentaram diversas imagens dos índios, relacionando-os com ricos territórios que imaginavam existir na Amazônia, como o El Dorado e o Paititi. Este artigo propõe uma análise mais aprofundada dessas imagens, entendidas não tanto como a permanência de uma predisposição mítica, mas como uma estratégia discursiva na dura negociação por mercês, honras e privilégios que os referidos atores estabeleciam com a Coroa espanhola. Embora os memoriais permitissem ao Consejo de Indias ter notícia de regiões distantes e de como colonos e missionários atuavam nelas, a própria função política do documento influía poderosamente no tipo de imagens que apresentavam dos indígenas e das paisagens fronteiriças.

Palavras-chave: Amazônia; El Dorado; Paititi; encomienda; memoriais; Consejo de Indias.

Imagining Amazonia in petitions sent to the Council of the Indies during the seventeenth century

Abstract: Throughout the seventeenth century, settlers and missionaries assiduously explored the Amazonian lowlands, located east of the Viceroyalty of Peru. The petitions that they sent to the Council of the Indies requested honors and awards for past or planned actions in the frontier. These documents also described Amazonian Indians and landscapes, relating them to rich imagined territories such as El Dorado and Paititi. In this article, I argue that these images must be understood not as a mythical predisposition, but as a discursive strategy for the negotiation of honors, awards, and privileges between local actors and the Spanish Crown. Although petitions provided information to the Council of the Indies about distant regions and the activities of settlers and missionaries who resided within them, the visions of Amazonian peoples and landscapes that they described were powerfully influenced by the political function of the document.

Keywords: Amazonia; El Dorado; Paititi; encomienda; petitions; Council of the Indies. 


\section{Introdução}

Juan Recio de León, colono radicado no Peru, fez, entre 1623 e 1627, sucessivas aparições diante do Consejo de Indias, em Madri, sempre com memoriais em que requeria licença para conquistar certas regiões amazônicas. Petições que, como tantas outras apresentadas por colonos e missionários nessa época, estavam permeadas por imagens fantásticas de populações e províncias e que conduzem à suspeita de que esses súditos tentavam fazer com que os mitos trabalhassem a seu favor. Tendo passado da Espanha ao Novo Mundo em 1604, Recio participara de algumas entradas às regiões setentrionais do Peru, nomeadamente em Apolobamba, e seu desempenho lhe valera o título de mestre de campo das províncias desconhecidas de Chunchos, Paititi e Dorado. Havendo aceitado o posto, realizara expedições àqueles territórios na década de 1620. Nos memoriais que apresentou ao Consejo de Indias, esse aventureiro espanhol assinalava a existência de metal precioso e de índios interessados em aceitar o cristianismo, manipulando com habilidade dois pontos que os fiscais daquele tribunal esperavam ouvir: ouro e almas. ${ }^{2}$

Estudos recentes têm repensado a influência do mito e do fantástico nas ações dos colonos e missionários espanhóis nas fronteiras do império. ${ }^{3}$ Acompanhar a tramitação de memoriais que solicitavam a conquista ou a redução de grupos amazônicos no âmbito do fluxo de informações entre as instâncias locais e o Consejo de Indias permite conhecer, de modo mais aprofundado, as formas por meio das quais as descrições dos nativos e da paisagem amazônicos integravam-se na negociação estabelecida entre colonos e missionários e o poder central. Em grande medida, nesses memoriais, colonos e funcionários solicitavam a Madri licença para a realização de expedições às terras baixas e a concessão de encomiendas; por sua vez, os religiosos requeriam auxílio para a realização de entradas missionárias e a jurisdição sobre determinados grupos nativos que esperavam reduzir. Nesse quadro, procura-se aqui analisar as dimensões sociais e políticas dos mitos de El Dorado e Paititi, isto é, o modo como colonos e missionários integravam imagens de riquezas minerais ocultas nas selvas às suas solicitações de recursos, mercês e honras ao poder central. Semelhantes imagens dos índios e da paisagem amazônicos somente podem ser adequadamente entendidas se restauradas as trajetórias dos autores dos textos e examinados os impactos de seus projetos sobre os nativos, suas relações com outros setores locais e seu processo de negociação com Madri.

${ }^{2}$ Os memoriais encontram-se em Archivo General de Indias (AGI), Sevilha. Lima, 159; para mais detalhes sobre esse colono, cf. Scott (2009, p. 130).

${ }^{3}$ Ver, entre outros, Lorandi (1997, 2000), Glave Testino (2007), Scott (2009), Combès (2011), Livi Bacci (2012) e Gómez González (2014). Para os memoriais de colonos da América portuguesa enviados durante a União Ibérica (1580-1640), ver Raminelli (2006) e Cardoso (2012) 
Memoriais eram requerimentos formais enviados por funcionários, colonos e missionários ao Consejo de Indias, em que solicitavam mercês por determinado serviço que alegavam haver realizado e/ou esperavam realizar com o auxílio do poder central. A análise de uma série numerosa e duradoura de memoriais permite captar a reiteração de padrões discursivos e verificar a variação das "descrições do real” segundo as disputas políticas, especialmente em torno da lealdade ou deslealdade dos atores locais aos desígnios do centro. ${ }^{4}$ Minha proposta é demonstrar que as imagens tecidas nesses memoriais a respeito dos índios e da paisagem amazônicos evidenciam, acima de tudo, que a negociação do poder político entre as instâncias locais e o poder central, vale dizer, entre funcionários, colonos e missionários, de um lado, e autoridades vice-reinais e o Consejo de Indias, de outro, moldava a forma como as populações nativas e seus territórios eram descritos. ${ }^{5}$

Em recente trabalho, Brendecke sugeriu que a comunicação dos colonos com o Consejo de Indias compunha o que chama de "triângulo vigilante". As instâncias locais não apenas mantiveram a comunicação independente com o centro como também se empenharam em informar a respeito da lealdade ou da deslealdade dos moradores. Os espanhóis residentes, ao contarem sempre com a possibilidade de enviarem informação, assumiam alternativamente as funções de atores e observadores. Os informes que escreviam, longe de "descrever o real", buscavam fundamentar uma ação passada ou futura, diante de outros atores/observadores: daí o formato dual de seus escritos, sempre a indicar uma ação (ordem, proposta, petição etc.) e uma situação (depoimentos, notícias, inventários etc.). Uma realidade de papel era criada, a qual fazia com que as ações aparecessem como consequência lógica dessa realidade, e não como mera expressão de interesses políticos particulares (Brendecke, 2012, p. 239, 254-259, 288).

A emergência do mito do El Dorado, em todo caso, é bastante conhecida. El Dorado era o termo utilizado pelos espanhóis para referir-se a toda a região supostamente aurífera por explorar, localizada ora no vale do rio Marañón, ora em Cumaná, ora em Tierra Firme, ora na Guayana, ora no rio da Prata (Espinoza Soriano, 2007, p. 42). Desde memoriais que

\footnotetext{
${ }^{4}$ Ao situar-se em uma posição de poder que iniciava, controlava e dirigia para si informações sobre os espaços distantes, o Consejo de Indias em Madri funcionava com certa similitude ao que Bruno Latour chama de "centro de cálculo". Entretanto, como argumenta o estudo de Brendecke, os fluxos de informação terão sido mais negociados do que o modelo de Latour parece sugerir. Em realidade, pessoas de todas as condições sociais aspiravam a apresentar-se diante do monarca para comunicar um serviço ou anunciar um mérito. Madri recebia as informações, mas não necessariamente as que solicitava ou esperava, e os súditos pareciam estar mais preocupados com eventuais interferências de outros interesses particulares, ou com a interrupção de sua comunicação com o poder central, do que com as perguntas que este último pudesse fazer (cf. Latour, 1987, p. 222 e 232-233; Brendecke, 2012, p. 100 e 254-259).

${ }^{5}$ Os suplicantes costumavam apresentar suas "probanzas" juntamente com seus memoriais, ou redigir estes últimos com uma maior ênfase sobre seus "meritos y servicios". Sobre esses escritos coloniais, ver Macleod (1998) e Folger (2011). O modo como as relaciones de méritos e serviços de clérigos definiam o conceito de idolatria é o objeto do estudo de Chuchiak (2002). Na mesma direção, Gabriela Ramos (1993, p. 139-140) analisou as relações de méritos e serviços de clérigos do Peru durante o processo de extirpação de idolatrias e mostrou que era interessante para os religiosos afirmar ou negar a presença das idolatrias, conforme as circunstâncias políticas.
} 
solicitavam ao Consejo de Indias a capitulação para a conquista e pacificação de determinados grupos indígenas e a exploração das riquezas minerais que supostamente existiam em terras amazônicas até títulos de governador que abarcavam imensas regiões, em grande medida incógnitas, nas quais se supunha existir metal precioso em abundância, o termo El Dorado reaparecia como sinônimo de província onde se acreditava existirem profusas riquezas, cuja localização e extensão eram ainda ignoradas pelos conquistadores. ${ }^{6}$

Em muitos memoriais, os autores referiam-se ao mito do Paititi como sendo uma versão do (ou mesmo o próprio) El Dorado. A rigor, apesar das diferenças importantes entre os dois mitos, não poucos colonos e missionários tratavam-nos como transferíveis e intercambiáveis e chegavam a confundir sua localização em algum ponto obscuro do interior da Amazônia. O Paititi era comumente referido como uma província localizada a leste das jurisdições de Santa Cruz de la Sierra, da Audiência de Charcas e de Cuzco. A depender da versão adotada, sua origem remontava às populações orientais submetidas pelos incas; aos grupos com que os chefes de Cuzco estabeleceram tratados de paz; às colônias incaicas fundadas nas fronteiras do império; ou, ainda, à fuga de lideranças do império durante a conquista espanhola, ocasião em que levaram consigo importantes tesouros, de modo a ocultá-los à cobiça do adventício. ${ }^{7}$ O termo Paititi podia referir-se, em cada situação, a uma

${ }^{6}$ O termo, contudo, inicialmente esteve circunscrito a uma situação bem concreta. A época da fundação de Quito, em 1534, deram-se a conhecer, de modo vago, notícias sobre a existência de um cacique que residia nas proximidades da lagoa Guatavitá (localizada entre as atuais cidades de Bogotá e Tunja, na Colômbia) que tinha o costume de cobrir seu corpo com uma camada de ouro em pó para realizar certas cerimônias religiosas (Simón, 1891 [c. 1627], v. 2, caps. 1 e 2. p. 242-243 e 245; Hemming, 1979, p. 53-58). O célebre cronista Gonzalo Fernández de Oviedo (1855 [1548], t. 4, liv. 49, cap. 2, p. 383) recolheu notícias que dão ideia das riquezas esperadas por quem buscava aquela lagoa: "este cacique o rey dicen los indios ques muy riquíssimo e grand señor, e con cierta goma o licor, que huele muy bien, se unta cada mañana, e sobre aquella unción assienta o se pega el oro molido o tan menudo como conviene". A razão disso seria "porque le paresçe a él que traer otro cualquier atavio es menos hermoso, [... es grosería e cosa común". O nome El Dorado foi aplicado a distintas fontes de ilusão que em nada se relacionavam com a primitiva cerimônia do cacique Dourado, buscado pelo fundador de Quito, Sebastián de Benalcázar, em fins dos anos 1530 (Bayle, 1943, p. 19-20 e 2527; Gandía, 1946, p. 125-128). Em 1539, Francisco Pizarro nomeara seu irmão, Gonzalo, para explorar o misterioso país de La Canela e, se possível, verificar a existência do El Dorado, mas coube a Francisco de Orellana, um dos membros da expedição, a descida do rio das Amazonas. A partir de 1547, Juan Pérez de Guevara percorreu o rio Huallaga em busca de uma reencarnação do El Dorado denominada Ruparrupa ("país ardente"), um império de riquezas inauditas perseguido também desde Chachapoyas e Huánuco (Hemming, 1979, p. 108-114; Espinoza Soriano, 2007, p. 62).

${ }^{7}$ Que as migrações dos incas a leste pudessem ter dado origem a um novo e igualmente rico império era uma hipótese levantada por numerosos autores. Já o colono de Cuzco Juan Alvarez Maldonado, que navegara os rios Madre de Dios e Beni à procura do Paititi, assegurava a presença de grupos incaicos nas terras baixas. Em sua "Relación" de 1570, afirmava que os índios que habitavam aquele anelado país chamavam-se corocoros (os da planície) e pamainos (os serranos). Vestiam-se à maneira dos do Peru, de modo que o suplicante supunha que eram descendentes dos incas. Belicosos, haviam impedido o avanço destes últimos, até que um dos incas tratou pazes com o senhor de Paititi e estabeleceu duas fortalezas na região. Território que, além de ouro e prata, era generoso em âmbar, chinchilídeos e pedras preciosas (AGI. Patronato, 151, n. 6, r. 1, f. 349-373, "Relación verdadera del discurso y subçeso de la jornada”, Juan Alvarez Maldonado, último de jul. 1570, f. 369 et seq. [f. 21 et seq.]). Garcilaso de la Vega, em seus Comentarios reales, publicados em 1609, lembrava que o sucessor do inca Pachacútec, Túpac Yupanqui, que dirigiu o império entre 1471 e 1493, organizara uma expedição ao país dos musus a partir de Cuzco. Os musus, de sua parte, aceitaram de bom grado a amizade dos incas. Com o tempo, os andinos instalaram colônias nas terras baixas (Vega, 1991 [1609], v. 2, liv. 6, cap. 13, p. 33-34; v. 2, liv. 7 , caps. 14-15, p. 116-120). Também o padre Diego Felipe de Alcaya, cura de Mataca, asseverou que o reino de Paititi teria sido fundado pelos incas pouco antes da conquista espanhola. Em sua "Relación cierta”, sugere que Mango Ynga, um 
lagoa, um cerro, um rio, um grupo indígena ou um cacique, sem ficar claro se era uma província separada ou se estava contida em outros países ricos imaginados nas terras baixas, como Mojos, Candire, Enim ou El Dorado (Levillier, 1976, p. 97-99; Saignes, 1985, p. 41 et seq.; Sanchez, 1996, v. 2, p. 705-709).

A Amazônia ocidental constitui um espaço privilegiado de pesquisa, especialmente entre os séculos XVI e XVII, época em que os colonos empobrecidos das cidades circunvizinhas empenhavam-se em apresentar à Coroa seus "méritos y servicios", com o fim de inclinar o favor real às suas súplicas de encomiendas e de outras mercês. Memoriais em que ressaltavam sua participação em entradas destinadas a atrair ou a reprimir grupos independentes, que conferiam, às encomiendas, um status de prêmio e direito de conquista.

Entretanto, as regiões de Quito e Charcas tiveram desdobramentos distintos. Ao norte, pela década de 1540, a busca do El Dorado e do país da canela partia de Jaén de Bracamoros, Chachapoyas, Huánuco, Yaguarzongo, Macas e Quijos. Alguns colonos conseguiram instalar-se nos vales dos rios Pastaza e Palora, e desde Quijos enviavam expedições denominadas correrías, com vistas a capturar índios para o serviço pessoal. Impulsionadas pela extração aurífera, essas cidades sofreram um duro golpe com a rebelião dos jívaros, sucedida em fins do século XVI, e com o esgotamento das minas (Renard-Casevitz et al., 1988, p. 265; Newson, 1996, p. 205; Espinoza Soriano, 2007, p. 66). Na região de Quijos, por exemplo, onde os encomenderos contavam, pelo ano 1608, com uma média de 40 a 50 tributários, as costumeiras alegações de pobreza e de que os braços já concedidos haviam desertado eram recorrentes em seus requerimentos. Também era comum afirmar que a comunidade havia sofrido ataques de "índios bárbaros" ou que existiam ricos minerais naquelas proximidades (Oberem, 1980, p. 90-106).

Mudando o que deve ser mudado, nos domínios lusitanos, alegava-se que, apesar da imensidade de produtos naturais que floresciam sem cultura alguma no estado do Maranhão, eles se perdiam por não haver quem os beneficiasse, e do mesmo modo as notícias de pedras e metais, ainda que certas, nada rendiam, por "pouco povoadas as terras e larga a distância", como escreve o vigário-geral Domingos Antunes Tomás pelo ano 1679. ${ }^{8}$ O contraponto entre as ideias de opulência e de miséria era, assim, recorrente, segundo apurou Chambouleyron (2005, p. 116-119) em informes seiscentistas sobre as potencialidades da Amazônia portuguesa. De um lado, opulência da natureza, abundância de especiarias e excelência das terras, dos rios e dos animais. De outro, a pobreza dos moradores e a miséria dos índios, decorrentes,

sobrinho do inca reinante, havia descido pelos rios orientais e instalado uma capital entre os "mojos", "gente limpia". O emissário que enviou a Cuzco, ao constatar que a cidade havia sido tomada pelos espanhóis, retornou ao Paititi com umas 20 mil pessoas, além de "ganados de la tierra y ofiçiales de plateria" (AGl. Charcas, 21, r. 1, n. 2, "Relación çierta", Diego Felipe de Alcaya, 23 mar. 1636, f. 23-23v). Na opinião de Levillier (1976, p. 97-99), a colonização que Mango Ynga empreendera teria alcançado a região atualmente conhecida como Serra dos Parecis.

${ }^{8}$ Biblioteca da Ajuda, 50-v-37, f. 394-397, "Sobre o Maranhaõ e Parà e cativ.ro dos Indios e forma de os haver cõ augmento do Estado", Lisboa, 3 nov. 1679, f. 394 apud Chambouleyron (2005, p. 116). 
segundo afirmavam os colonos, de se privilegiarem as atividades extrativas ao cultivo das terras e da falta de gente de serviço - uma forma de reivindicar à Coroa licença e guarida legal para o recurso ao trabalho dos cativos indígenas.

Quanto ao oriente da jurisdição da Audiência de Charcas, o ponto de partida era a cidade de Santa Cruz de la Sierra, estabelecida por Nuflo de Chaves em 1561. As populações indígenas que ocupavam as savanas e estepes tropicais que se espraiavam pelos vales dos rios Beni, Mamoré, Madeira, Guaporé e Pilcomayo foram acossadas por espanhóis que buscavam o quimérico Paititi e sua serra de prata, ou que com esse pretexto capturavam índios para o serviço pessoal (Finot, 1939, p. 279 et seq.; García Recio, 1988, p. 50-62 et passim; Livi Bacci, 2012, p. 73).

Do mesmo modo, data de fins do século XVI a exploração das franjas da Amazônia por jesuítas e franciscanos, que principiavam suas atividades missionárias entre os nativos. ${ }^{9}$ Embora os jesuítas tivessem instalado as missões de Maynas em 1638, eles só se fixaram em Mojos e Chiquitos a partir de 1682. Os franciscanos, pelas décadas de 1630 e 1640, atuaram fortemente no vale do rio Napo, e, cerca de 40 anos depois, começaram a trabalhar entre os índios de Apolobamba. Até as últimas décadas do século XVII, quando as missões religiosas se afirmaram em detrimento das expedições de colonos, setores seculares e eclesiásticos atuaram ao mesmo tempo, mas sua colaboração em entradas conjuntas nem sempre se efetivava.

Se, para os missionários, a busca de apoio entre as autoridades coloniais para as reduções que esperavam fundar na fronteira amazônica orientava as imagens que construíam a respeito dos índios, do ponto de vista dos colonos o mais urgente era a obtenção de licenças para a realização de expedições e de concessões de encomiendas entre os grupos contatados. Estudos recentes têm mostrado que as imagens fantásticas a respeito dos índios e da paisagem das terras baixas da América do Sul, que adornavam os memoriais que os colonos submetiam ao Consejo de Indias, longe de expressar uma predisposição pelo maravilhoso, decorrente de um suposto "contágio" pela "febre" do El Dorado, ${ }^{10}$ respondiam, em realidade, a interesses mais concretos. Essas imagens eram mobilizadas e manipuladas, de forma oportunista - vale dizer, atenta ao que as autoridades de Madri esperavam ouvir - , por aventureiros e buscadores de fortuna de diversas origens sociais, mas que se encontravam em regiões marginais e desprovidos de recursos. Daí por que, na dura negociação com os funcionários reais, as imagens do El Dorado e do Paititi podiam compor um discurso suficientemente persuasivo para obter a adesão da Coroa se não a pedidos de governações e títulos,

${ }^{9}$ Entre as obras que abordam esse processo, ver, além das supracitadas, Rumazo González (1946), Block (1994), Newson (1995) e Tomichá Charupá (2002).

10 Ramos Pérez (1973, p. 375, 398 e 404), que sugere que o "contágio" era favorecido por uma eventual predisposição mítica dos espanhóis, lembra que a principal influência, no entanto, era "racional", a saber, as noções clássicas de que as terras equinociais eram potencialmente auríferas. 
ao menos a súplicas mais urgentes de licenças para a realização de expedições e a concessão de encomiendas (Lorandi, 1997, p. 187-209; Scott, 2009, p. 109-113).

Duas grandes questões emergem a partir da problemática até aqui esboçada, e elas serão examinadas no decorrer deste artigo. Os primeiros itens tratam da manipulação dos mitos de El Dorado e Paititi por colonos e missionários. Imagens de riquezas minerais ocultas nas selvas eram incluídas em solicitações de licença para a realização de expedições às terras baixas, pedidos de concessão de encomiendas, ou mesmo em requerimentos de auxílios para entradas missionárias. Os tópicos seguintes tratam das dinâmicas sociais e políticas por trás da tramitação dos memoriais e seu papel no fluxo de informações entre as instâncias locais e o Consejo de Indias. Fatores como a origem social dos suplicantes, a competição entre as diversas esferas do poder local e da burocracia colonial e as diretrizes de Madri em relação aos territórios de fronteira foram condicionantes para o êxito ou o fracasso dos projetos contidos nos memoriais.

\section{A manipulação do fantástico}

A hidrografia fantástica era um elemento recorrente nos memoriais de colonos e missionários, em que faziam constar descrições confusas e tortuosas dos rios das terras baixas e, no mais das vezes, alternavam ou sobrepunham as localizações do El Dorado e do Paititi. Em 1567, o referido morador de Cuzco, Juan Alvarez Maldonado, dava livre vazão à sua imaginação a respeito do destino dos rios amazônicos e da localização do Paititi. Tendo capitulado uma licença para entrar neste último país com o vice-rei Lope García de Castro, pretendia "poblar" uma Nova Andaluzia em um imenso território que alcançava até a costa do Brasil.." Sua entrada navegou pelos rios Madre de Dios e Beni. A certa altura, o destacamento comandado pelo capitão Escobar se adiantou e acabou aniquilado pelos índios, o que obrigou a expedição à retirada. Maldonado deu conta, de forma mais pontual, sobre suas entradas no informe "Relación verdadera del discurso y subçeso de la jornada", escrito em fins de julho de 1570. Com a noção fantástica de geografia que lhe era peculiar, referiu que todos os rios que nasciam na descida dos Andes confluíam com a lagoa de Paititi, cujo rio do mesmo nome desaguava no mar do Norte, a mais de mil léguas. ${ }^{12}$ Maldonado chegou a requerer ao vice-rei Toledo nova licença para entradas, a qual foi denegada (Levillier, 1976, p. 103-112).

Que as famosas guerreiras amazonas fossem localizadas nas proximidades do El Dorado era algo recorrente nos memoriais do século XVII, mas o já mencionado Juan Recio de León desenhava uma hidrografia com pressupostos tão fantásticos que a origem de todos os rios

"AGI. Patronato, 151, n. 6, r. . , "Provisión del licenciado Lope García de Castro", Los Reyes, 25 jul. 1567.

${ }^{12}$ AGI. Patronato, 151, n. 6, r.1, f. 349-373, "Relación verdadera del discurso y subçeso de la jornada", Juan Alvarez Maldonado, último de jul. 1570, f. 369 et seq. [f. 21 et seq.]. No antigo sistema espanhol, uma légua equivalia a 5.572,7 metros. 
amazônicos era buscada em uma lagoa oculta na floresta. Em certo passo de sua "Breve relación", de 1623, esse aventureiro espanhol anotou que os índios guarayos lhe haviam dado notícia que da banda norte do rio Apurima, "confines del Paytite", encontrava-se "una Provincia de mugeres, que vivian sin hombres, y pregundandoles que como podian conservarse de aquela manera, dixeron, que hombres tenían [su residencia] en la otra vanda del Paytite al leste". ${ }^{13}$ Os índios anamas teriam dito que, caminhando quatro dias, se chegava a uma grande lagoa chamada Cocha, e que nela havia muitas ilhas povoadas "de infinita gente", e que seus caciques eram tão ricos que traziam como adornos pessoais "pedaços de ambar, por ser amigos de olores, y conchas y barruecos de perlas, lo qual vide yo en algunos Anamas". ${ }^{14}$

E em um exemplo notável de geografia fantástica, Recio de León conectava a lagoa de Paititi com a do El Dorado: caminhando ao norte de uma cordilheira nevada, que se levanta junto à lagoa de Paititi, chegava-se ao Novo Reino de Granada, e nesse caminho havia populações riquíssimas de prata e animais de carga. ${ }^{15}$ Evidência de que distava pouco a lagoa de Paititi das paragens onde os holandeses e ingleses incursionavam, a partir da Guayana, eram as ferramentas adquiridas pelos índios por resgates de metais preciosos, pedras e especiarias. ${ }^{16}$

O autor apresentava as províncias a serem conquistadas como um único e imenso território, que ia do Cerro de la Sal e de Apolobamba ao mar do Norte. Eram regiões que contavam com 100 léguas de rios caudalosos e navegáveis, "hasta los confines del Paytite, y grande Laguna del Dorado". A origem dos rios amazônicos deve ser buscada nessa lagoa, de onde partem dois rios, um dos quais desemboca no Marañón, e o outro, no Amazonas. ${ }^{17}$ Realmente, quanto mais imprecisa fosse a localização do país imaginário, tanto maior a curiosidade que se esperava despertar nas autoridades coloniais. Recio em nenhum momento esclarece se seu "Paititiy Dorado" seria uma lagoa ou duas; nem fornece qualquer delimitação pontual sobre sua localização. Seria vizinho de Mojos? De Apolobamba? Da província de Chunchos? ${ }^{18}$ Igualmente perturbadora era sua observação de que os holandeses, que entravam pela costa setentrional do continente, apareciam naquela província para tratar e contratar com os índios. ${ }^{19}$

Também os jesuítas sabiam que o mito do El Dorado continuava sumamente atrativo para as autoridades do poder central. Daí por que o padre Cristóbal de Acuña, em sua relação de 1641, em que narra sua viagem de descida do Amazonas, região que pretendia como exclusiva

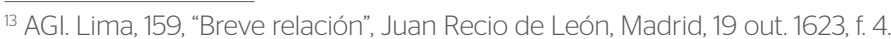

${ }^{14}$ Ibidem

${ }^{15}$ Ibidem, f. 4V.

${ }^{16}$ Ibidem, f. 5.

${ }^{17}$ Ibidem, f. 6v. Para terminar, como se intentasse desarmar os céticos, afirmava que um dos males de sua época era que ninguém acreditava nas relações "fantásticas", razão pela qual não se faziam mais descobrimentos interessantes: "El vicio establecido en el mundo a no dar credito a cosas que de presente no se veen" (Ibidem, f. 4v).

${ }^{18}$ AGI. Lima, 159, "Breve relación”, Madrid, 19 out. 1623.

${ }^{19}$ AGI. Lima, 159, Memorial de Juan Recio de León [lido em Madri, 7 jan. 1627], f. 1v.
} 
para a jurisdição da Companhia de Jesus, retomava o mito daquela fantástica lagoa. ${ }^{20}$ Além das evidências de existência de minas, com a ampla difusão de adornos corporais de metal precioso, teve conhecimento de que um "lago dorado" se encontrava nas proximidades onde os rios Tapi, Catuá e Araganatuba (Paraná Copeá?) deságuam no Amazonas. Acuña trata das margens a jusante do atual rio Solimões, depois da foz do rio Tefé ou do lago Caiambé até, provavelmente, a foz do rio Paraná Copeá. Entrando no vale do Araganatuba, existiam numerosas nações, que o jesuíta nomeia cuidadosamente. ${ }^{21}$ Apesar de não desenvolver o tema, o inaciano é suficientemente enfático para não deixar dúvidas sobre o país em questão: "Entre estas naciones [...] está el deseado Lago Dorado, que tan inquietos tienen los ánimos de toda la gente del Perú" (Acuña, 2009 [1641], p. 135, \$ 60).

Mas seria possível que o Paititi e o El Dorado fossem a mesma coisa? Na opinião do capitão Gregorio Ximénez, espanhol residente em San Lorenzo de la Frontera há três décadas, sim: "según discurso de hombres vaquianos es toda una", apenas os nomes e as direções em que era buscada variavam: no Paraguai, falava-se Paititi; no Peru, Mojos; e em Nova Granada, Dorado. ${ }^{22}$ Outros simplesmente permutavam os elementos dos mitos de El Dorado e Paititi. Em 1564, Diego Alemán intentou uma entrada a Paititi desde Cochabamba, vindo a perecer no episódio. Uma "Memoria de la tierra de Los Llanos" refere que, depois dos Pacaxas, "luego está el Paitite". Na grande lagoa que ali existia, uma ilha alojava um templo, "adonde los indios de todas estas provincias van a sacrificar a sus dioces", chamado Casa do Sol. Nas proximidades, uma província de mulheres guerreiras, chamada Pañeca. ${ }^{23}$ O modelo, na opinião de Juan Gil (1989, t. 3, p. 298), era análogo ao do El Dorado, sem deixar de fora a lagoa, a Casa do Sol e as amazonas.

Por sua vez, a homologia entre Paititi, Mojos e Candire é verificada, por exemplo, em certo escrito do mercedário frei Diego de Porres, que dizia haver andado por Santa Cruz de la Sierra e proximidades da "noticia Rica", "que es el Reyno del Candire Guazu, y los Moxos, y el Paitite, y la provincia de las Amazonas”. ${ }^{24}$ Mais tarde, o padre jesuíta Andrés Ortiz, em carta ao padre provincial escrita em 1595, dava conta de uma expedição que realizara desde San Lorenzo

\footnotetext{
${ }^{20}$ O Nuevo descubrimiento do padre Acuña foi acompanhado de um memorial que defendia a jurisdição jesuíta sobre o grande rio, recentemente navegado por franciscanos e portugueses (AGI. Quito, 158, f. 43-47v, “Memorial”, padre Cristóbal de Acuña, S.J., Madri, 1641).

${ }^{21}$ Os grupos são os seguintes: yaguanais, mucunes, mapiarús, aguainaús, huirunas, marirúas, yamorúas, terarús siguiyas, guanapuris, piras, mopitirus, iguaranis, aturiaris, macaguas, masipias, guayacaris, anduras, caguaraús, maraimumas e guanibis (Acuña, 2009 [1641], p. 135, § 60).

22 AGI. Charcas, 21, r. 1, n. 11, bloque 7, f. 15-19, "Parecer del capitán Gregorio Ximénez", San Lorenzo, 30 nov. 1635, f. 15v.

23 "Memoria de la tierra de Los Llanos segundo se pudo saber por indios que habitan allá", [1564] (In: Relaciones Geográficas de Indias [RGI], 1897, t. 4, p. cxcvii-cc, cit. p. cxcvii-cxcviii).

24 "Memorial del padre fray Diego de Porres a S.M. pidiendo mercedes por sus servicios", 1582 (In: Maurtua, 1906, t. 9, p. 82-86, cit. p. 85)
} 
de la Frontera, indo sempre pelas margens do rio Guapay, "por tener noticia que ribera dél hay población que han de dar noticia de los Mojos o Paytitin (asî) o Candire, como acá le llaman". ${ }^{25}$

As amazonas e o El Dorado continuavam a ser imagens mobilizadas mesmo por estrangeiros que apareciam em Madri e submetiam seus memoriais ao Consejo de Indias. ${ }^{26}$ Era esse o caso do irlandês Bernardo O'Brien del Carpio, que chegou àquela Corte em 1636. Seu pedido de capitulação para a conquista dos índios amazônicos estava assentado em uma longa lista de serviços prestados às potências do norte, ingleses e holandeses, desde 1621, com duas importantes viagens à Amazônia. ${ }^{27}$

O mais notável no memorial de del Carpio está em afirmar que ele não apenas tivera notícias das amazonas, como se entrevistara com a grande senhora delas. Efetivamente, essas mulheres eram chamadas pelos demais índios de Cuña Atenare, "mugeres varoniles": "Estas tienen las tetas de pechos chicas, como los hombres, con artificio de modo que no crecen para tirar las flechas, $y$ las esquierdas largas como otras mugeres, están armadas como los indios." Sua rainha se chamava Cuña Muchú, "señora grande", e as conversações de del Carpio com ela se resumiram aos comprimentos e trocas comerciais, que consistiram em três escravas por mercadorias, como camisa de Holanda e outros produtos. ${ }^{28}$ Não chega a surpreender que se seguisse daí uma conexão entre as amazonas e o almejado El Dorado, e o autor refere que, segundo pôde se informar, naquelas imediações existia uma terra chamada Hanauaca, onde "hay pedras cristalynas, y otras resplandezientes, que los indios estiman mucho por ser buenas contra melancolia, y mal del bazo". ${ }^{29}$

Quando os "capitães de Paititi" eram chamados a dar depoimentos, de modo a formar a "informação", documento certificado que geralmente acompanhava os memoriais que os suplicantes de mercês apresentavam em Madri, as imagens fantásticas a respeito do Paititi ou do El Dorado pareciam não ter limites. Uma "informação", instruída pela Audiência de Charcas em 1644, apresentava fartos depoimentos de sujeitos práticos que

\footnotetext{
25 “Annua de la Compañía de Jesús - Tucumán y Perú - 1596: Misión o Residencia de Santa Cruz de la Sierra” (In: RGI, 1885, t. 2, p. Ixvi-xcii, cit. p. Ixxix). A assimilação entre o Paititi e o Candire, nome então atribuído a um país, e não a um grupo indígena, servira a Thierry Saignes (1985, p. 49-50) para sugerir a hipótese de que o mito da Terra sem Mal, que os guaranis teriam equiparado ao Candire, impulsionou esses índios em direção ao noroeste e, com eles, os conquistadores do Paraguai. Ao mesmo tempo, do lado andino, o refúgio do inca em Vilcabamba se projetava em um oriente mais distante, que vinha a identificar-se com o Paititi. Em ambos os casos, Candire e Paititi pareciam remeter aos grupos indígenas do vale do rio Mamoré. Em estudo recente, Isabelle Combès (2011, p. 83-84) questionou os pressupostos dessa hipótese e mostrou que a assimilação entre Paititi e Candire não perdurou nas fontes.

${ }^{26}$ Gandía (1946, p. 83) havia procurado elementos andinos nas imagens das amazonas, mas já o padre Bayle (1943, p. 200) invalidara essa possibilidade. Para um estudo recente em que as origens clássicas do mito são expostas em detalhe, ver Ugarte (2009, p. 429-437)

${ }^{27}$ Do período que residira por três anos na Amazônia, a partir de 1621, como participante da expedição inglesa, afirmava haver conhecido muitas e diversas parcialidades. Os ingleses teriam subordinado os nativos, a quem teriam obrigado a entregar o excedente de tabaco e algodão. Ao mesmo tempo, teriam iniciado práticas de evangelização entre esses índios que, em seu parecer, não cultuavam ídolo algum (AGI. Indiferente General, 1872, "Memorial de don Bernardo Obrian del Carpio, irlandés", Madri, 1636, f. 2)

${ }^{28}$ Ibidem, f. 2V.

29 Ibidem, f. 3.
} 
haviam entrado nas regiões onde se supunha existir o Paititi. A documentação foi composta para fazer parte do memorial de Francisco Rodriguez Peinado, que servira como capitão em Santa Cruz de la Sierra, às ordens de Suárez de Figueroa, e fora responsável por abrir o caminho daquela cidade a La Plata, em 1609. Certo Miguel Díaz afirmava ter ouvido um índio dizer que existia na comarca de Paititi um pueblo composto exclusivamente de artesãos, cujo ofício se resumia a lavrar, de dia e de noite, aquilo que se extraía em abundância daquelas terras, isto é, o metal dourado. ${ }^{30}$

Não se pode negar que havia um horizonte de recepção favorável ao fantástico, e os que manipulavam as imagens para que se aproximassem das expectativas dos receptores quanto às riquezas fabulosas, se é certo que participavam dessa mentalidade, podiam utilizar-se de estratégias racionais e oportunistas coerentes com seu arrivismo político (Maravall, 2012, p. 38; Lorandi, 1997, p. 205). Não surpreende, nesse sentido, que um jurista nascido em Valladolid, filho de cristãos-novos portugueses, Antonio de León Pinelo, erudito conhecedor dos negócios ultramarinos, como assessor do Consejo de Indias e compilador de cédulas reais, preparasse, enquanto vivia no Peru, uma obra com o título de El paraíso en el Nuevo Mundo. Escrevendo pelos anos 1645 a 1650, munido de elevados conhecimentos de geografia, cosmografia e de referências latinas, gregas e hebraicas, León Pinelo (1943 [1656], liv. 2, cap. 3, t. 1, p. 137, 139) efetivamente sustentava que "el lugar del Deleite que el Texto santo llama Eden" encontrava-se no centro da América Meridional, "circunscripto a un circulo imaginario de nuebe grados de diametro que son ciento y sesenta leguas, y quatrocientas y sesenta de circunferencia". Os quatro rios bíblicos eram identificados da seguinte forma: o rio da Prata seria o Fisón; o Amazonas, o Geón; o Orinoco, o Eufrates; e o Magdalena, o Tigre.

\section{Das pedras às piezas}

Imagens de populações indígenas opulentas, que se supunha existirem nas vizinhanças de — ou mesmo em - províncias que ocultavam poderosas minas de metal precioso e outras riquezas, permitiam aos colonos justificar a incorporação de grupos indígenas fronteiriços em encomiendas. Nos memoriais em que solicitavam licença para conquistar esses territórios, os colonos podiam manipular essas imagens, de modo a incorporar os grupos nativos às futuras encomiendas que seriam concedidas como prêmio por aquele serviço à monarquia.

O rio Marañón continuou a ser entendido como um espaço onde existiam fabulosas riquezas, se não as do El Dorado, pelo menos a da mão de obra nativa. Assim, por exemplo, já em 1602, certo Manuel de Zurita Noguerol solicitou o título de capitão da conquista daquele rio e faculdades para instalar uma fazenda em que trabalhariam até 400 índios sob

${ }_{30}$ AGl. Charcas, 90, n. 4, "Informaciones de Francisco Rodríguez Peinado, maestre de campo", 1629. 
o regime de encomienda, com a alegação de que parte das utilidades seriam gastas com o bem espiritual e temporal dos referidos nativos. ${ }^{31}$

Entre os colonos de Quijos, a floresta afigurava-se como um verdadeiro El Dorado da mão de obra indígena. Alonso de Miranda, governador de Quijos, resolveu promover entradas aos omaguas, dirigidas, em um curto espaço de tempo, pelos capitães Pedro de Palacios, Francisco Bermúdez, Gabriel Machacón e Juan de Robles. Ao que parece, essas expedições retornaram com não menos que 300 cativos, ou, como se dizia à época, piezas. ${ }^{32} \mathrm{Na}$ opinião do historiador Juan Gil (1989, t. 3, p. 250), nessas entradas pouco contribuíram quaisquer sentimentos em favor da evangelização dos índios: antes, tratava-se de expandir as encomiendas e de alcançar uma base política suficiente para os memoriais que seriam apresentados ao Consejo de Indias, com as habituais súplicas de governações de amplos territórios.

Por outro lado, foi recorrente, entre os memoriais que chegaram ao Consejo de Indias, nos séculos XVII e XVIII, a alusão a que o território dos jívaros era aurífero e que ali havia existido a antiga cidade de Logroño. ${ }^{33}$ A existência de uma caixa real em Logroño e o levantamento dos jívaros contra essa cidade foram lembrados também por Christóbal de la Serna, corregedor da cidade de Cuenca. Em memorial apresentado em 1633, ele pedia licença para a conquista e pacificação da província de Jívaros. Aí é dito que das minas de Santa Bárbara se sacavam vultosos quintos reais, "el mayor rendimiento que se a visto en estos reynos del Piru". Aludia ainda a que os índios se levantaram certa noite, mataram todos os espanhóis e índios amigos, e queimaram a cidade de Logroño e outros pueblos circunvizinhos. ${ }^{34} \mathrm{O}$ mesmo suplicante atribuía à influência do demônio a apostasia dos índios jívaros, pois o inimigo comum esperava recuperar seu antigo império, devolvendo "a los que se hicieron xtianos, a su miserable idolatria". Agregava, ainda - argumento pouco utilizado no caso desses índios - , que os jívaros eram caribes, "conmiendo carne humana de estos naturales que coxen y comen bien assados".

\footnotetext{
${ }^{31}$ AGI. Lima, 321, “Memorial q.' le dio al P.e Confesor de Su Mag.d”, anterior a 1602, f. 1v. Não se pode deixar de notar que a solicitação de Manuel de Zurita subiu ao poder central por mãos do padre jesuíta Juan Font, quando capitulava licença para suas entradas. As relações entre Zurita e o padre Font não são de todo claras, nem o porquê desse jesuíta interceder por benefícios que nada tinham a ver com o estritamente missionário. Alguns contemporâneos notaram que ambos dirigiam um empreendimento mineiro desde a missão de Cintiguailas, como mostra Regalado de Hurtado (1991, p. 328). ${ }^{32}$ AGl. Quito, 50, Alcalá del Río Dorado, 15 jan. 1620; Memorial de Alonso de Miranda, 18 abr. 1620. Diante da indecisão das autoridades, celebrou-se uma informação sobre o assunto em Alcalá del Río Dorado, em setembro de 1630. O capitão Gabriel Machacón assumiu a defesa mais enfática da entrada, que em sua opinião ia dar com "otro nuevo Perú". Destacou, ademais, a bondade do clima, a abundância de frutos e a docilidade dos índios omáguas e abegiras, sensíveis à eficaz pregação do jesuíta Melchor Velázquez de Ovando (AGI. Quito, 83, f. 16 et seq.. Testemunho de Gabriel Machacón, 11 set. 1630).

${ }^{33}$ Segundo as pesquisas de Kris Lane (2002, p. 139-140), entre setembro de 1561 e abril de 1567, 167 mineiros registraram na caixa de Zamora 210 mil pesos (cerca de $875 \mathrm{~kg}$ ) em ouro. Nesse último ano, 27 encomenderos atuavam na região, onde contavam com o trabalho de oito mil jívaros. Uma rebelião desses índios, sucedida em fins do século XVI, teria posto fim àqueles empreendimentos.

${ }^{34}$ AGI. Escribania, 924b, “Christóbal de la Serna”, Quito, [1633], f. 1-1v.
} 
Sendo o mais lamentável que atacassem os mesmos índios cristãos, a exemplo dos maynas, que perderam 60 vidas para esses bárbaros em tempos recentes. ${ }^{35}$

Eis, portanto, um caso exemplar de memorial que atrelava uma imagem sumamente negativa dos índios à crença de que as regiões em que viviam eram auríferas, como forma de obter do poder central as licenças de conquista e concessão de encomiendas, de modo que o El Dorado que se imaginava era, mais uma vez, um paraíso da mão de obra a ser integrada ao serviço dos colonos. É assim que o referido capitão Christóbal de la Serna solicitava aval e apoio para "ir a la dicha conquista castigo y reducción encomendar y repartir los indios por tres vidas por todos los conquistadores y pobladores". ${ }^{36}$

No caso presente, o fiscal não aderiu à proposta e lembrou as cédulas reais de 1610 e 1632 , que interditavam a conquista e a redução dos índios por força das armas. ${ }^{37} \mathrm{O}$ presidente de Quito, por sua vez, em seu parecer, alegava que os vizinhos das províncias fronteiriças faziam entradas contra os jívaros sem licença da Audiência. Essas entradas, em geral, fracassavam e eram mais prejudiciais que os próprios índios inimigos contra quem eram dirigidas. Contudo, como o suplicante de la Serna dava mostras de ter recursos para custear a entrada, não via inconvenientes para que se lhe concedesse a licença que pedia. ${ }^{38} \mathrm{O}$ sucessor no governo de Maynas, Maurício Vaca de Vega, também consultado sobre o assunto, alertava que o território dos jívaros estava sob sua jurisdição e que, portanto, devia ser denegada a petição de Cristóbal de la Serna, dados os esforços já realizados entre os índios daquela província no sentido de reduzi-los à polícia cristã. ${ }^{39}$ As consultas continuaram sem que a Audiência, o vice-rei e o Consejo de Indias determinassem nada de positivo sobre o assunto. ${ }^{40}$

Também as entradas de Martín de la Riva Herrera, pela década de 1650, nas terras baixas amazônicas, estiveram orientadas à incorporação de encomiendas para os moradores da fronteira de Chachapoyas, ainda que fosse utilizado o pretexto de minas de metal precioso ocultas na província de Jívaros. Riva Herrera, aliás, também pretendia somar o governo de Maynas ao desta última cidade, que ele já governava, em razão de não haverem mais descendentes de Diego Vaca de Vega com direitos sobre aquela província. Grande soma de nativos e serem as terras férteis e abundantes de alimentos, "de mucho oro y plata", eram as razões em

\footnotetext{
35 Ibidem, f. 2-2v.

${ }^{36}$ Ibidem, f. 2.

${ }^{37}$ Ibidem, f. 3: "Parecer del fiscal".

${ }^{38}$ Ibidem, f. 5-5v: "Parecer del Señor Pres.te de Quito".

39 Ibidem, f. 7v: "Informe de don Juan Mauricio Vaca".

40 Para alguns, o metal precioso obtido nas minas de Potosí não podia ser comparado às riquezas que prometiam as províncias de Jívaros. Em uma representação elevada em 1641, em que pedia se the fosse confiada uma entrada aos Jívaros, o governador de Quijos e Macas, Francisco Mogollón y Ovando, insistia que "la dicha tierra es la más rrica que oy se halla en estos Reynos, pues se conoce que respectivamente dió de quintos en cinco o seis años que estubo de paz, más que ha dado todo este Reyno del Perú desde que está poblado" (AGI. Quito, 32, "Petición” ante a Audiência de Quito, 18 mar. 1641). O memorial gerou um pleito com o governador de Maynas, Pedro Vaca de la Cadena, que reclamava para si os direitos sobre aquela província (cf. Revista de Archivos y Bibliotecas Nacionales, 1899, p. 232-247 e 265 et seq.).
} 
que apoiava sua demanda. ${ }^{41}$ Uma real cédula de 17 de abril de 1650 aprovou as condições com que se oferecia Riva Herrera a realizar a redução dos motilones, tabalosos, pabalosos, casas blancas, omagos e demais índios amazônicos. Essas condições incluíam algumas cláusulas importantes, que permitem ter uma ideia das garantias que ambas as partes acordavam em capitulações desse tipo. O suplicante recebia a prorrogação do ofício de corregedor de Cajamarca por mais quatro anos; a promessa do título de governador perpétuo das províncias que reduzisse; e a promessa de que poderia encomendar por três vidas os índios que pacificasse. Em contrapartida, estava obrigado a deixar uma fiança de 30 mil ducados para o caso de não realizar o serviço acordado. ${ }^{42}$ Riva Herrera partiu de Moyobamba em outubro de 1654, acompanhado de cem soldados espanhóis. Em Concepción de Jeberos, requisitou o auxílio de 50 índios cristãos. Sua entrada à província de Jívaros, em julho de 1655, não alcançou mais do que capturar alguns nativos, sofrer baixas de soldados e constatar a indisposição dos índios para servir aos colonos.

O essencial a notar aqui é que as encomiendas continuavam a ser uma instituição importante para os espanhóis que viviam naquela fronteira. Como devesse fundar ao menos uma cidade para manter o cargo de governador, Riva Herrera instalou um estabelecimento nas margens do rio Pastaza, a alguma distância de sua entrada no Marañón e próximo à lagoa de Rimachuma. Os moradores foram trasladados da cidade de Borja (40 famílias) e de Santiago de las Montañas e receberam índios roamaynas e conchas, repartidos em 47 encomiendas. ${ }^{43}$ Fundada a 25 de julho de 1657, a nova cidade recebeu o nome de Santander de la Nueva Montaña. A seu redor, os referidos grupos indígenas foram assentados em quatro pueblos. ${ }^{44}$ Em Triunfo de la Santa Cruz, outra das supostas fundações, foram repartidas 28 encomiendas, compostas por índios motilones, tavalosos, pobalosos, payananços, lamas e fuines. ${ }^{45}$ Braços indígenas e ouro eram inseparáveis nesses informes, e quando Riva Herrera prestou contas sobre as cidades que fundara, não deixou de lançar mão do pretexto do metal dourado - que um informe do padre Figueroa asseverava não existir — para angariar apoio da Coroa, da qual esperava as remunerações pelos serviços e gastos: se os espanhóis de Borja, a quem Riva Herrera pedira um testemunho favorável, podiam afirmar "tenerse noticias ciertas ay cerca minerales ricos de oro en que esperamos a de tener grande augmento el rreal patrimonio", ${ }^{46}$

\footnotetext{
${ }^{41}$ Memorial de Martín de la Riva Herrera, 1648 (In: Revista de Archivos y Bibliotecas Nacionales, 1899, p. 10-12).

${ }^{42}$ Real cédula ao vice-rei do Peru, Madri, 17 abr. 1650 (In: Revista de Archivos y Bibliotecas Nacionales, 1899, p. 43-49).

${ }^{43}$ AGI. Lima, 169, Certidão dos documentos apresentados, Cajamarca, 18 abr. 1657 (sello de 1656-1657), f. 2v.

${ }^{44}$ AGI. Lima, 169, Informe do padre Francisco de Figueroa, Santander de la Nueva Montaña, 13 ago. 1656, f. 1v

${ }^{45}$ AGI. Lima, 169, "El cabildo de Santiago de Moyobamba”, 26 out. 1656, f. 1v; e AGI. Lima, 169, Informe de Salvador de Velázquez Medrano, Cajamarca, 22 jan. 1657, f. 9

${ }^{46}$ AGI. Lima, 169, Informe do cabildo da cidade de San Francisco de Borja, sobre as entradas de Martín de la Riva Herrera, Borja, 13 ago. 1656
} 
segundo informação do citado jesuíta, era "tierra estéril asperísimos descollados altos cuchillas y peñascos y de oro no allaron sino muy poco". ${ }^{47}$

O caso de Santa Cruz de la Sierra é particularmente relevante aqui, porque, em que pese o fato de as expedições não deixarem de lado o Paititi e outros reinos imaginários, o problema da falta de mão de obra tornava-se, a pouco e pouco, uma motivação abertamente assumida pelos colonos (García Recio, 1988, p. 50-62 et passim). Esse problema era já digno de nota em abril de 1601, quando um informe da lavra do jesuíta Diego Martínez dava conta de que, entre os índios que serviam aos espanhóis naquela cidade, tinha ocorrido, nos últimos anos, a causa de "hambres y pestilencias", uma surpreendente diminuição, passando os que atendiam ao serviço das encomiendas de 10 ou 12 mil para 6 ou 8 mil. ${ }^{48}$ Pelo mesmo relato, fica-se sabendo dos procedimentos das expedições dirigidas pelos cruceños a Mojos, tendo o jesuíta Jerónimo de Andión participado de uma entrada em que foram 80 soldados rio Guapay abaixo: "hicieron lo que suelen de maldades matando indios y captivando todos los que pudieron aver a las manos", refere o cronista. ${ }^{49}$ Para capturar trabalhadores indígenas, sucessivas entradas desciam o rio Guapay até sua confluência no Mamoré, eventualmente chegando ao seu deságue no Madeira. ${ }^{50}$ Como informa o padre Juan de Soto, o pretexto da entrada de 1667 era capturar índios de serviço que teriam fugido e atacar os cañacures, "índios bárbaros" do Alto Mamoré que supostamente ameaçavam a província. Apesar de considerar uma lástima ver índios perder sua liberdade e serem tratados como escravos, Soto argumentava que o fato de eles atacarem os mojos amigos, e manterem costumes bárbaros, como a antropofagia, tornava legítima a guerra e sua captura para o serviço dos colonos. ${ }^{51}$ Assim, esvaecido

\footnotetext{
${ }^{47}$ AGl. Lima, 169, Informe do padre Francisco de Figueroa, Santander de la Nueva Montaña, 13 ago. 1656, f. 1; cf. AGl. Lima, 169, "Autos hechos por el general don Martín de la Riva en rraçon de la fundación y población de la ciudad de Santander de la Nueva Montaña", início em 18 jul. 1656 (sello de 1656-1657), f. 3. Os índios das missões de Maynas se alvoroçaram ao ver que os roamaynas, retirados de suas terras com o pretexto de missão, tinham sido entregues como encomiendas aos colonos de Santander. Os jesuítas conseguiram reverter o quadro e, com o apoio do vice-rei, Riva Herrera foi removido do governo de Maynas e substituído por Juan Mauricio Vaca de Eban. Em seguida, a cidade de Santander foi desfeita, e os índios roamaynas, liberados das encomiendas (Lucas de la Cueva ao vice-rei, San Francisco de Borja, 30 nov. 1657. In: Revista de Archivos y Bibliotecas Nacionales, 1899, p. 517-520; Parecer do Senhor Fiscal, 1658. In: Ibidem, p. 566-569). Cf. Jouanen (1941, v. 1, p. 422).

${ }^{48}$ Archivum Romanum Societatis lesu (Arsi), Roma. Peru, v. 26, f. 403-446, "Misión de Sancta Cruz", padre Diego Martínez, Chuquisaca, 24 abr. 1601, f. 446.

49 Ibidem, f. 445.

${ }^{50}$ Entre as principais, há de se destacar as entradas de Suárez de Figueroa, das quais participou o padre Andión e foi dar no Alto Mamoré, em 1596; a coordenada pelo governador Juan de Mendoza Mate de Luna, em 1602, com 130 soldados, cheia de padecimentos pela inadaptação às terras baixas; as de Solís de Holguín, em 1617 e 1624, tendo participado desta última o jesuíta Navarro; e a de Diego de Ampuero, em 1667, da qual fez parte o jesuíta Juan de Soto (Finot, 1939, p. 279 et seq.: Livi Bacci, 2012, p. 73).

${ }^{51}$ O jesuíta Juan de Soto considerava como justificativa "el que hagan ellos guerra a n.tros amigos, gente miserable y desdichada, q.' no les ofenden ni ocasionan, y que los maten, y se los coman, vicio bestial, y ferino, y digno de ser castigado, por cualquier príncipe y señor político, y humano" (Arsi. Peru, v. 20, f. 130-138v, "Relación de lo sucedido en la jornada de los Mojos, año de 1667", por Juan de Soto, Plata, 30 jan. 1668, f. 137). Nessas entradas "mistas", os jesuítas eram coniventes com as ofensivas direcionadas contra índios que presumiam inimigos e "caribes". Sobre outra entrada, Soto escreveu que "los españoles tuvieron que repartir a dos piesas a cada uno; con que todas estas almas vienen a la
} 
o pretexto do Paititi, os cruceños passaram a alegar que as entradas eram necessárias para recuperar os índios de encomiendas que teriam fugido ou reprimir aqueles havidos por "caribes", que supostamente atacavam os que eram amigos dos espanhóis. O historiador García Recio (1988, p. 70) estima o início dessa transição, na fronteira de Santa Cruz de la Sierra, a partir de fins da década de 1660. Às entradas que se fundavam no pretexto de buscar os primitivos mitos se somavam outras, em que os objetivos concretos eram já abertamente declarados: a captura de mão de obra indígena, por parte dos colonos, e o esforço por reduzir os nativos em missões, por parte dos missionários.

Predominava, portanto, nas expedições espanholas às regiões interiores do continente, a pretexto da pesquisa por metais e pedras preciosas, a busca de piezas, mão de obra indígena para os empreendimentos coloniais sob a forma de encomiendas. Não o maravilhoso, mas o interesse econômico imediato comandava as ações dos castelhanos. É certo que não desprezavam o sobrenatural e o fantástico, mas viam neles, antes, um material com que podiam trabalhar imagens oportunistas a respeito dos índios e da paisagem, inclusive com a retomada do mito do El Dorado, de modo a convencer as autoridades coloniais a concederem apoio às expedições. Em Visão do paraíso, Sérgio Buarque de Holanda (2000, p. 56, 165) mostrou como, na América portuguesa, com a pretensão de buscar pedras e minas nas regiões interiores, os colonos voltavam de suas expedições com "peças". Nessa obra clássica, em que o autor se concentra no "realismo pedestre" dos lusitanos, entendo que as diferenças que alude sobre as predisposições míticas entre os ibéricos são mais de grau que de espécie. Pois não há como negar que, no período aqui analisado, o discurso fantástico era recorrente no fluxo de informações da América espanhola; entretanto, pouca atenção até agora foi dada, neste último caso, ao modo como as imagens da Amazônia podiam justificar não apenas as explorações em busca de metal precioso, mas - e principalmente - a incorporação dos índios ribeirinhos aos empreendimentos coloniais das cidades adjacentes.

\section{Quimeras e instabilidade social no Peru}

A utilização dos elementos discursivos até aqui descritos decorria da própria composição social dos que adentravam o processo de negociação com as autoridades reais. Em grande medida, eram colonos desprovidos de encomiendas, pessoas que migraram para as Índias sem recursos ou que foram preteridas em concessões anteriores de índios tributários. O século XVII presenciou, no vice-reinado peruano, a emergência de um amplo setor de colonos despossuídos, à margem dos empreendimentos produtivos e na órbita das instituições do Estado, sem desfrutar de posições relevantes em cargos públicos, religiosos e militares.

christiandad" (Arsi. Peru, v. 2O, f. 142-144v, "Relación de la misión de los Mojos”, Juan de Soto ao padre provincial, Trinidad, 3 nov. 1668, f. 143). 
Mas um contingente populacional que, apesar de tudo, buscava sua inserção no status quo vigente, almejava a posição de encomendero e cargos importantes na administração colonial, como as governações e os corregimentos. Alguns dos memoriais foram escritos precisamente por colonos pobres e mestiços, mas, mesmo quando os proponentes eram religiosos, funcionários coloniais ou militares, os soldados para as expedições eram recrutados entre aquela gente considerada desocupada e turbulenta. ${ }^{52}$

Os missionários (jesuítas, franciscanos e de outras ordens) tiveram muita dificuldade para propor entradas independentes das dos colonos espanhóis, e as missões que fundaram continuaram permeáveis às expedições em busca de metais e "peças". ${ }^{33}$ Por sua vez, os memoriais de colonos, ao solicitarem como prêmio a governação de vastos territórios, não se esqueciam de pedir também a jurisdição necessária para conceder os nativos em encomiendas aos soldados que participavam das expedições. ${ }^{54}$

Realmente, o número de colonos sem um lugar estável na sociedade do vice-reinado do Peru, em 1555, já era preocupante. Naquele ano, o vice-rei marquês de Cañete estimou, em uma carta bastante conhecida, que havia no Peru oito mil espanhóis, dos quais apenas 480 ou 500 contavam com encomiendas e aproximadamente o mesmo número desempenhava algum cargo governamental, como escrivães e funcionários, o que deixava o país inundado com um contingente potencialmente explosivo de ociosos e descontentes. ${ }^{55}$ As entradas, nesse sentido, cumpriam um papel de válvula de escape (Saignes, 1985, p. 41). ${ }^{56}$ Assim, compreende-se por que o tema da obtenção de encomiendas podia ser tratado sem reservas em memoriais que, a princípio, alegavam como prioridade da expedição a descoberta de países fantásticos como o El Dorado e o Paititi.

Daí por que o poder central não procurava proibi-las; e não tanto por que a gente ociosa e inquieta pudesse realizar um serviço útil à república, quando descobriam alguma coisa ou fundavam uma cidade ou uma missão, mas apenas com seu distanciamento já se conseguia apaziguar, ao menos momentaneamente, os conflitos entre os conquistadores. Tal era a opinião do vice-rei conde de Chinchón, que escrevia em 1629: "lo que entiendo es que siempre

\footnotetext{
52 Sobre a base social das entradas às terras baixas, ver Lorandi (2000) e Glave Testino (2007).

${ }^{53}$ Sobre esse problema, ver Medina Rojas (2005, p. 213) e Maldavsky (2012, p. 79).

${ }^{54}$ A permanência das encomiendas em regiões de fronteira dependeu, em parte, do esforço dos setores locais em manter suas prerrogativas, mas também do interesse do poder central em transferir parte dos custos defensivos aos próprios colonos, como mostram, entre outros: Saeger (1981, p. 68, 69-70, 72-73 e 78), García Bernal (1990, p. 80-83) e Vitar (1997, p. 128-29 e 136).

55 “Carta a S.M. del Marqués de Cañete”, 30 maio 1555 (In: Levillier, 1921, t. 1, p. 252-253). Lockhart (1982, p. 21 e 176-177) ponderou que os números do vice-rei, em geral corretos, superestimavam a população desocupada, que deve ter orçado pelos quatro mil colonos, o que não deixava de ser um grave problema social.

${ }^{56}$ O próprio vice-rei Cañete terá visto no envio de expedições a melhor forma de neutralizar essa crise social ao franquear todo o apoio necessário à jornada de Pedro de Ursúa às terras baixas do nordeste. Assim, em 1558, esse colono recebia o título de capitão-geral de Omagua, El Dorado e rio Marañón, e licença para fundar cidades e repartir terras e encomiendas em um vasto território que ia dos Motilones do Peru à costa atlântica (Espinoza Soriano, 2007, p. 76-77).
} 
que se pueden escusar las d.has entradas, lo tengo por más conveniente y de menos costa, si no fuere en alguna ocasión que convenga divertir por este camino la gente ociosa que suele haver". ${ }^{57}$

Com o tempo, contudo, percebeu-se que as próprias entradas às terras baixas podiam ser um fator adicional e agravante aos distúrbios sociais que ameaçavam a estabilidade do vice-reinado. Essa era a opinião do vice-rei Francisco de Toledo em carta ao rei enviada 1572. A gente pobre que se somava às "huestes" era enganada e roubada por seus caudilhos, que logravam capitulações com argumentos geralmente fictícios: "muchos españoles vassalos de VM que dexan en ese Reyno hijos y mugeres perdidos" eram "engañados y aun rrovados" por "pícaros", "bagamundos y perdidos". No mais das vezes, eram recrutados para expedições fingidas, das quais jamais se podiam esperar resultados concretos, pois tão logo viam alguns índios e afirmavam a posse das centenas de léguas, que lhes eram concedidas nas capitulações, retornavam às cidades ou à Corte do vice-reinado e ali permaneciam, de modo a garantir que ninguém lhes retirasse seus direitos. Como exemplo, ironizava a demarcação dada a Pedro Maraver de Silva, que era tão grande que "todas las lagunas de los Dorados" estariam incluídas nela. As entradas eram, portanto, um distúrbio social que colocava em risco a própria segurança do governo das Índias: "que ahora que me cuesta tanto travajo tomalla VM crea el gran deservicio que se haze a dios y el descredito de n.tra nación y descomposición de govierno y peligro de las siguridades del rreyno que es causa con las entradas de la forma susod.ha". ${ }^{8}$

O perfil social daqueles que participavam de expedições e enviavam memoriais era o da gente pobre do vice-reinado. As expedições reuniam aventureiros e buscadores de fortuna, colonos espanhóis e mestiços sem ocupação fixa na sociedade colonial, sem encomiendas e sem dinheiro. Já em seu informe sobre uma entrada realizada às terras baixas amazônicas, em 1557, Salinas Loyola assinalava que os homens que o acompanhavam tinham semelhante perfil: 250 soldados faltos de tudo, com os quais fora preciso gastar uns 50 mil ducados para socorrê-los com armas, munições, petrechos, cavalos, roupas e mantimentos. ${ }^{59} \mathrm{E}$ como as fazendas e bens do caudilho não bastassem para financiar a expedição, era preciso fazer dívidas: "vine gastando y adeudando por el descubrimiento dicho, y después por la población de las cuatro ciudades que poblé, con que se añadieron deudas a deudas y gastos a gastos". 60

As autoridades, por outro lado, desconfiavam particularmente das entradas conduzidas por mestiços. Assim, em 1621, o vice-rei Esquilache foi informado de uma entrada feita à província dos Chunchos pelo religioso franciscano Gregório de Bolívar, em companhia do mestiço Diego Ramírez Carlos. Expedição que lograra atrair cinco caciques, que foram

${ }^{57}$ AGI. Lima, 42, f. 64-64v, “Carta del conde de Chinchón”, 18 maio 1629, f. 64v.

58 AGI. Lima, 28-B, f. 155-166, Carta do vice-rei Toledo ao rei, Cuzco, 10 mar. 1572, f. 158-159, § 11-12. O El Dorado, como enfatizou um estudo recente sobre o tema, podia servir de pretexto para os arrivistas ao simbolizar a busca de novas riquezas (metais e braços), "un pretexto para obtener financiaciones y motivar a ignorantes, crédulos y desesperados" (Livi Bacci, 2012, p. 23)

59 Informe de Juan de Salinas Loyola [Madri, 1571] (In: RGI, 1897, t. 4, p. Ixxxiii-Ixxxvii, cit. p. Ixxxiii).

60 Ibidem. 
conduzidos à cidade de La Paz, onde deram mostras de obediência de suas províncias às majestades Divina e Humana. ${ }^{61}$

As consultas sobre a viabilidade da entrada de Diego Ramírez Carlos causaram polêmica na Corte do vice-reinado. ${ }^{62} \mathrm{O}$ ilustre jurista Solórzano Pereira, em seu parecer sobre o caso, recomendava prudência, dado que havia recebido cartas de frei Gregório "en que descubre los engaños de este mestizo". ${ }^{63} \mathrm{Na}$ mesma direção, o fiscal Nicolás Polanco de Santillana, um crítico dos memoriais e entradas a El Dorado e Paititi, entendia que era preciso desconfiar dos mestiços - provavelmente enfatizava esse aspecto em razão de que eles eram a maioria dos que apresentavam memoriais - , "porque en todas las estorias de las indias y alçamientos leo siempre que an sido complices y cabeças". Daí por que rechaçara o pedido do filho ilegítimo (mestiço?) do finado governador de Tucumán, Florian Gil Negrete, por licença para entrar no que chamava "imperio de gran Paitite" ${ }^{64}$ Vale lembrar que, nessa época, o termo "mestiço" era pejorativo. "A los hijos de español y de india o de indio y española, nos llaman mestizos, por decir que somos mezclados de ambas naciones”, escrevia o Inca Garcilaso de la Vega (1991 [1609], v. 2, liv. 9, cap. 31, p. 266). "En Indias, si a uno de ellos le dicen 'sois un mestizo' o 'es un mestizo', lo toman por menosprecio". ${ }^{65}$

Tudo indica que esse frei franciscano, Gregório de Bolívar, teve problemas com Diego Ramírez Carlos, nas entradas que fizeram aos chunchos. As relações entre Bolívar e Ramírez Carlos não eram das melhores, e o religioso passou a criticar sistematicamente a conduta do mestiço, chegando a pedir, em outubro de 1621, que ele fosse proibido de entrar na fronteira. Seu argumento principal era o de que a estratégia de Ramírez Carlos para fazer-se obedecer pelos índios comuns, como um novo inca, não oferecia garantias às autoridades de que não pudesse favorecer algum alçamento: "se puede dar su Magestad por agraviado y deservido de el tal hecho por ser derechamente contra su Real persona y corona, pues se pretende introducir nuevo Rey y Inga mayormente en persona de tan pocas obligaciones, de las cuales

\footnotetext{
${ }^{61}$ AGI. Lima, 97, "Acuerdo sobre la entrada de los chunchos que se ordenó hiziesen los religiosos de San Francisco y Diego Ramírez Carlos”, Lima, 22 abr. 1621; e AGI. Lima, 97, Memorial de Diego Ramírez Carlos, La Paz, 17 maio 1619.

${ }^{62}$ Chamados a opinar sobre o assunto, vários religiosos apresentaram suas reservas, mas, ao menos nesse estágio inicial, deram sua aprovação. O parecer do padre comendador dos mercedários sintetizava as dúvidas ao assinalar que o maior receio era o de que "el dicho Diego Ramires Carlos puede en esta entrada viéndose de algunos indios respetado perder el respeto devido al Rey nuestro señor y alzarse con la jurisdicción real". Também o prior dos agostinianos manifestava preocupação com o fato de o mestiço "decir que deciende de los ingas", mas considerava que essa estratégia permitiria que fosse respeitado entre os índios (AGI. Lima, 97, "Autos primeros", La Paz: parecer de frei Luis Bernal, mercedário, 23 maio 1619; e parecer de frei Mateo Ortiz, agostiniano, 26 maio 1619).

${ }_{63}$ AGI. Lima, 97, Carta de Juan de Solórzano Pereira, Lima, 10 out. 1621.

${ }^{64}$ AGI. Lima, 102, “El fiscal Nicolás Polanco de Santillana”, Lima, 31 jul. 1663, f. 3-3v.

65 Mesmo no termo alternativo que alguns preferiam abraçar, montañés, não deixava de residir certa malícia, como indicava Garcilaso, dado que era uma tradução da palavra quíchua sacharuna, que designa os salvajes do piemonte amazônico, chamado montaña. Para mais detalhes sobre as identidades dos mestiços no Peru, ver Saignes e BouysseCassagne (1992, p. 15)
} 
no sé quién es el que se atreva a asegurar de una vez introducido, no resultará daño alguno". ${ }^{66}$ Como quer que seja, os eventos seguintes são conhecidos: o bispo considerou melhor dar outro capelão para as entradas de Ramírez Carlos, concretamente o franciscano Bernardino de Cárdenas, mas já na primeira expedição que, em 1622, eles fizeram ao Alto Beni desde Camata, o mestiço foi preso pelas autoridades do vice-reinado (Glave Testino, 2007, p. 21-25, 47-48; Ibáñez Bonillo, 2011, p. 205).

O financiamento das entradas às terras baixas era um problema delicado, tendo em vista que, geralmente, aqueles que as propunham eram aventureiros pobres ${ }^{67}$ Daí que contasse muito sua capacidade de persuasão e de mobilização de notícias de países e populações opulentos escondidos nas selvas, imagens que, antes de serem destinadas às atenções de Madri, deviam convencer, ao menos, alguns colonos prósperos que pudessem custear as primeiras entradas exploratórias e mesmo a viagem do suplicante àquela Corte.

Era comum que os que escreviam memoriais alegassem deter bom crédito entre comerciantes e outras pessoas de cabedal, que, segundo informavam, lhes haviam prometido todo o auxílio necessário. Assim é que Alvaro Enríquez del Castillo, quando propôs uma capitulação para a conquista da Amazônia até a ilha de Margarita e parte do Brasil, afirmava que "le ayudarán mercaderes y otras personas con cuarenta mil pesos, y se han ofrecido a ir con él ciento cincuenta vecinos casados y hacendados con hijos y mujeres y entre ellos oficiales de todos oficios, y catorce sacerdotes clérigos y frailes" ${ }^{6} 8$

Os memoriais mantinham o teor persuasivo com que seus autores buscavam convencer, inicialmente, aquelas pessoas de cabedal que pudessem financiar seus empreendimentos, e algo desse tom propagandístico chegava aos senhores do Consejo de Indias. Frei Amich (1988 [1771], p. 51), por exemplo, ao comentar um memorial de Pedro Bohorquez da década de 1630 (infelizmente perdido), assinalou alguns dos expedientes retóricos que este último utilizava para "fisgar" apoiadores à entrada que planejava ao país de Enim, um fabuloso império escondido nas terras baixas, "a cuyo emperador hace señor de muchos reinos, que le tributan vasallaje en oro, mantas, plumajes, y otros géneros riquísimos”. ${ }^{69}$ Amich (1988 [1771], p. 51) alude que,

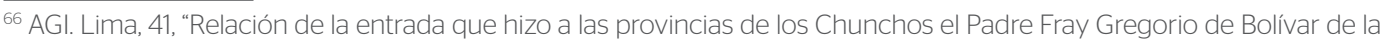
Orden de S. Francisco en compañía de Diego Ramírez Carlos el año de 1621” (In: Colección de documentos que apoyan el alegato de Bolivia en el juicio arbitral con la república del Perú, 1906, t. 1, p. 173-214, cit. p. 208).

${ }^{67}$ Em 1606, por exemplo, pretendeu a conquista dos jívaros certo Martín de Ocampo, então corregedor de Cuenca (AGI. Quito, 18, Carta de Martín de Ocampo, Cuenca, 12 abr. 1606; AGI. Quito, 26, n. 56, "Carta de Martín de Ocampo a S.M.", Cuenca, 20 abr. 1606; e AGI. Quito, 27, n. 13, "Carta de Martín de Ocampo a S.M.", Cuenca, 20 mar. 1608, com minuta da real cédula datada de Madri, 4 maio 1607). O vice-rei Montesclaros rechaçou o pedido e assinalou que o requerente não contava com meios suficientes: "se buscará persona a propósito y de caudal" (AGl. Lima, 35, v. 1, f. 68, Carta do vice-rei marquês de Montesclaros, 12 abr. 1608).

68 “Real cédula al virrey del Perú, marqués de Montesclaros”, Madri, 26 jan. 1612 (In: RGI, 1897, t. 4. p. cxxiv-cxxV, nota 2).

${ }^{69}$ Esse andaluz chegara ao Peru em 1620. Desprovido de recursos, passara a viver em regiões periféricas, habitadas por índios e negros que, ao que parece, Ihe forneceram notícias sobre o Paititi e o El Dorado. Suas entradas se dirigiram principalmente às terras baixas adjacentes ao Cerro de la Sal (cf. Lorandi, 1997, p. 313).
} 
nesse memorial, Bohorquez narra a origem desse império, traça a árvore genealógica de seus soberanos, descreve seu governo e costumes, as cerimônias de coroação dos imperadores, a vassalagem prestada pelos reis vizinhos. Tudo isso "con circunstancias tan bien ordenadas y dispuestas a su antojo, que admitidas de la novedad que el vulgo suele abrazar sin examen, muchas personas de distinción se persuadieron ser cierta su existencia, y con eso alborotó los ánimos de mucha gente del Perú". Mas as esperanças em torno desse nebuloso reino logo se esvaíram, pois sendo Bohorquez obrigado a realizar a entrada, "fueron tales las excusas y tramoyas que armó, que dieron a conocer su falsedad, y que la fingida quimera del Enim había sido hija de su ambición". 70

Como buscadores de fortuna como Pedro Bohorquez convenciam seus seguidores e patrocinadores e, não raramente, algumas autoridades reais? Em primeiro lugar, procuravam desenhar, como em uma imagem refletida, cidades inexistentes habitadas por populações ricas em pedras e metais preciosos, além de especiarias (baunilha, salsaparrilha, canela, pimenta e outras), quadro que remetia a um paraíso de abundância, espaço ideal onde seus habitantes adornavam-se com os melhores sinais de vida política. Não espanta que os índios descritos por Bohorquez fossem mais brancos que os do Peru, usassem barba e tivessem cabelos claros. ${ }^{71}$ Em segundo lugar, com essa descrição hiperbólica, procuravam interessar as autoridades para que lhes brindassem o apoio de que necessitavam; para tanto, tratavam de demonstrar seus méritos como conquistadores de novos reinos, que seriam postos a serviço do rei de Espanha, isto é, apresentavam-se como merecedores de reconhecimento público e premiações. Finalmente, e esse ponto era particularmente crucial na estratégia de Bohorquez, apresentavam-se como mediadores indispensáveis entre os agentes da colonização e os índios "bárbaros". ${ }^{72}$

Os que conseguiam ir a Madri para advogar em favor de seus memoriais encontravam poderosos obstáculos. Causava indignação o fato, referido por Salinas Loyola - que foi àquela capital em 1571 reclamar premiação pela entrada realizada em 1557 às terras de Maynas - de que outras pessoas, que não haviam concorrido com gastos próprios, ou nem mesmo entrado na Amazônia, alcançavam mercês de extensos territórios. ${ }^{73}$ A espera em Madri para ser despachado durava meses, e a demora fazia com que os suplicantes reclamassem de terem consumido seus recursos, o que agravava a desilusão com os sucessivos memoriais denegados: "a todo se me cierra la puerta, ques lo que hasta ahora he conseguido de jor-

\footnotetext{
${ }^{70}$ Mesmo quando os que eram atraídos por essas aventuras eram fidalgos endinheirados, a perseguição dos mitos de países imaginários terminava por drenar as fortunas de uns e outros. Amich (1988 [1771], p. 51) menciona uma relação a respeito do "Gran Paytiti”, divulgada pelo ano 1638 por certo Gil Negrete, com a qual se deixou enganar um colono de La Paz, Benito de Ribera y Quiroga. Suas expedições, realizadas por volta de 1680, apenas ocasionaram a despesa de mais de 300 mil pesos, sem que recolhesse outro fruto que enfermidades, desengano e terminar pobre.

${ }^{71}$ AGI. Indiferente General, 631, "Memorial de Pedro Bohorquez", Lima, [1651], f. 1-Iv.

72 Ibidem, f. 1v-2. Esses três aspectos são destacados por Lorandi (1997, p. 186-187).

${ }^{73}$ Informe de Juan de Salinas Loyola [Madri, 1571] (In: RGI, 1897, t. 4, p. Ixxxiii-Ixxxvii, cit. p. Ixxxvi).
} 
nada tan larga, custosa y trabajosa y de nueve meses que ha questoy en esta Corte consumiendo la vida y lo demás".$^{74} \mathrm{~A}$ atitude desconfiada de Madri em parte decorria da enxurrada de memoriais que, em meados do século XVII, apareciam naquela Corte, um espaço que se havia convertido, nas palavras de John H. Elliott (1977, p. 170), em "an irresistible magnet to petitioners, place-hunters, and pícaros from all over Spain".

Neste tópico, foi visto que as entradas cumpriam um papel de válvula de escape. O distanciamento solucionava, ao menos momentaneamente, os conflitos entre os conquistadores. Os assentamentos fixados na fronteira serviam de base para novas expedições, mas é certo que a maior parte das entradas fracassavam por causa das desavenças entre os caudilhos e da resistência dos nativos das regiões de fronteira em servir em encomiendas aos espanhóis. Realmente, se o vice-rei conde de Chinchón pôde encontrar certa utilidade em algumas expedições, isso não se devia apenas a que, em seu entendimento, elas divertiam a gente ociosa e inquieta do vice-reinado, mas sobretudo porque, quando corriam inteiramente à própria custa dos suplicantes e resultavam em fundações de cidades e missões, a Coroa recebia um serviço útil e sem dispêndio de recursos da Real Hacienda. Assim sucedeu com a jornada de Diego Vaca de Vega a Maynas: os soldos, armas e petrechos dos que participaram da entrada correram por conta daquele caudilho, sem causar o menor ônus às caixas reais; a cidade que fundara, San Francisco de Borja, deu mostras de estabilidade ${ }^{75} \mathrm{e}$ tornou-se o ponto de partida das missões jesuíticas na Amazônia.

\section{Estratégias discursivas}

Como costumava suceder, as cidades fundadas nas fronteiras serviam para engordar os méritos e serviços dos suplicantes, e tão logo faziam sua aparição nos memoriais, desapareciam dos territórios que eram capitulados. É assim que o vice-rei Esquilache escrevia ao rei em 1618 a respeito da província dos "plateros", que a cidade de San Francisco de Alfaro acabou por ficar "pendiente sin continuar en esta población persona alguna hasta que buelto a ella por horden mía yntentó al principio del verano poblar en la cordillera de los Chiriguanaes". ${ }^{76} \mathrm{O}$ que era tanto mais de lamentar-se, pois havia notícias de que os espanhóis chegaram a firmar uma aliança com os torococies contra seus inimigos, e que entre aqueles nativos havia uma sólida rede de comércio de peças de prata, vindas de uma "gente rica" que habitava mais para o interior."

\footnotetext{
74 Ibidem, p. Ixxxvii.

75 AGI. Lima, 42, f. 64-66v, “Carta del conde de Chinchón”, 18 maio 1629, f. 64v-65v.

${ }^{76}$ AGI. Lima, 38, v. ano 1618, f. 311-313v, “Carta del virrey Esquilache al Rey”, 16 abr. 1618, f. 311.

77 Ibidem, f. 312v-313.
} 
Os memoriais de Riva Herrera se destacavam, por seu turno, pelo cuidado desse "conquistador" em apresentar as fundações de cidades e de reduções de índios segundo os protocolos considerados legítimos pelas autoridades coloniais. Um procedimento típico era o de alegar que, porque foram estabelecidas algumas conversações de paz com chefes nativos e porque, segundo a interpretação dos suplicantes, esses caciques deram mostras de aceitar o cristianismo e a obediência ao rei, daí se seguiria que os grupos em questão, e seus territórios, já estavam integrados à monarquia. Em não raros casos, esta última conclusão era extrapolada a partir de indícios incertos, como a aceitação, por parte dos índios, dos presentes que os espanhóis levavam consigo e o estabelecimento de conversações por intérpretes, nunca suficientemente clarificadas. A diplomacia fronteiriça parecia ser capaz de converter instantaneamente índios independentes em vassalos fiéis: os autores dos informes esperavam inculcar que, como resultado dos primeiros contatos, os caciques confirmavam sua vassalagem ao rei e aceitavam incondicionalmente a fé católica. Certamente estava implícita, nessas formulações, a política contida no requerimiento escrito pelo jurista Palacios Rubios, em 1513, como se nota pelo que Riva Herrera fez constar em seus memoriais: de algumas nações, por não atacarem os espanhóis e receberem seus presentes, era afirmado simplesmente "que quedaron muy sugetas y obedientes". ${ }^{78}$ Naturalmente, tratava-se de um acontecimento político cuja teatralidade era construída não apenas no plano do discurso: antes de chegar a um assentamento indígena, o caudilho enviava com bastante antecedência um índio ou cacique, devidamente aparatado e instruído para divulgar os benefícios de oferecerem a paz aos espanhóis, com o que procurava evitar ser recebido de forma hostil (o que amiúde ocorria). ${ }^{79}$

Outro aspecto importante da diplomacia fronteiriça era o protocolo de tomada de possessão dos territórios. Ao mesmo tempo que era preciso que os caciques se declarassem por vassalos do monarca espanhol, o caudilho que comandava a expedição devia caminhar pelas terras nativas e dizer a palavra "possessão" para os rios, as árvores, o terreno, os animais, as plantas e tudo o mais que encontrasse. ${ }^{80}$ Assim, em julho de 1654 , ao tomar posse do território dos porontos e fundar nele um pueblo, Riva Herrera "passeo por la plaça diciendo posesión posesión posesión". ${ }^{81}$

\footnotetext{
${ }_{78}^{7 G}$ Al. Lima, 169, Informe dos clérigos que acompanharam a expedição, Redução dos Tabalosos, 18 nov. 1654, f. 1. Sobre o requerimiento de 1513, ver Zavala (1988, p. 215-217) e Seed (1995, p. 72, 88 e 97). Assim, por exemplo, quando a expedição passou, em julho de 1654, pelos índios porontos, cuja língua, ao que parece, era conhecida pelo intérprete Francisco Mollicen, sucedeu que este "les dio a entender que no yba a hazerles daño ninguno, sino a ser su amigo y que fuesen christianos y conociessen por rey y señor natural a Phelipo el Grande por cuya orden yba"; ao que os índios responderam, todos juntos, "que querían ser christianos, y bautiçandose y que rreconocerían por su rey y señor a SM a quien desde Iuego rendian bassallaje y no faltarían a la fee que se devía tener" (AGI. Lima, 169, "Testimonio de lo que a obrado el gov.r d. Martín de la Riva Herrera en la reducción de diferentes prov.as de Ind.s”, sello de 1652-1653, f. 11v).

79 lbidem, f. 14.

80 AGI. Lima, 169, “Testimonio de lo que a obrado”, sello de 1652-1653, f. 5v, à margem.

81 ibidem, f. 12
} 
Do mesmo modo, anos antes, Pedro Bohorquez também alegava haver fundado cidades na selva, mas nenhuma fonte independente confirma a existência desses estabelecimentos. Foram fundações apenas textuais? Esta última hipótese parece menos provável, pois os memoriais de Bohorquez referem decisões tomadas pelo cabildo que indicam um mínimo de organização. Além disso, descrevem as celebrações em que o andaluz conseguira reunir os caciques locais e entronizar-se como seu chefe supremo. ${ }^{82}$ Os acontecimentos posteriores sugerem que os expedicionários e os nativos que se uniram a Bohorquez, em vez de se fixarem nos núcleos recém-fundados, acabaram por formar uma milícia mista que, segundo se sabe, passou a realizar incursões contra as estâncias dos moradores de Tarma e Jauja. Por essa razão, Bohorquez foi preso pelas autoridades do vice-reinado e degredado para o Chile, de modo que as cidades que fundara, se chegaram a existir, foram apenas efêmeras (Amich, 1988 [1771], p. 59).

Além disso, esses colonos e missionários apresentavam-se como interlocutores indispensáveis com os índios. Andrés Salgado de Araujo, morador de Lima, apareceu em Madri, em 1663, para capitular a conquista de um impreciso território onde existiam o El Dorado, o Cerro de Ialpay, as Llanadas de Osamarca, a lagoa de Paititi, o rio Marañón e certos assentamentos neoincaicos. Salgado de Araujo afirmava-se como o único mediador que podia conduzir com êxito aquele negócio, por haver firmado pazes com o cacique Tarisca e porque os outros chefes e naturais tinham-no em alta conta e confiança. E alertava: "si el suplicante no volvia por allá, se avían de resistir con cruda guerra a los españoles que intentassen volver a ella". ${ }^{83}$

Um morador da cidade de Chachapoyas, Alvaro Enríquez del Castillo, para que lhe fosse dada licença para conquistar e governar os motilones, tabalosos e os demais índios do rio Marañón, salientava que esses nativos, regalados com afabilidade e bom trato, "an dicho y publicado que por mi mano quieren su pacificación". ${ }^{84}$ Em outro papel, afirmava: "estoy bien a todos y a nadie agraviado y que los yndios de paz y cristianos me quieren bien, y los de guerra me aman y quieren $y$ piden la salvación por mi mano de sus almas". ${ }^{85} \mathrm{O}$ vice-rei não havia aderido às propostas anteriores, sob alegação de que os vecinos da cidade desmentiram-no.

Constante nos memoriais, portanto, era o fato de que os autores sempre representavam a si mesmos como interlocutores indispensáveis com as populações indígenas. De forma recorrente, afirmavam que os índios lhes queriam bem, que haviam feito acordo com os caciques, que entendiam seus códigos culturais ou mesmo sua língua, e que se outra pessoa coordenasse a entrada haveria grande risco de que sofresse a hostilidade dos nativos e malograsse. ${ }^{86}$

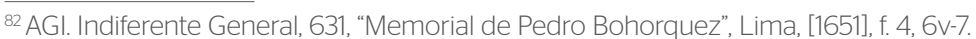

${ }^{83}$ AGI. Indiferente General, 631, “Memorial de Andrés Salgado de Araujo”, 1663, f. 2.

${ }^{84}$ AGI. Lima, 141, "Méritos de Alvaro Enríquez del Castillo", 1611.

${ }^{85}$ AGI. Lima, 141, "Relación de la jornada de los motilones y el río Grande el Marañón”, Lima, 24 abr. 1611, f. 4v.

${ }^{86}$ Em seu memorial, Pedro Bohorquez refere que um irmão franciscano, Melchor Fernández de Monterey, realizara uma entrada independente e tentara convencer os índios a aceitarem-no como missionário, mas os nativos "le rrespondieron
} 
Mais de um suplicante adotou a estratégia de entronizar-se como novo inca, de modo a construir um império artificial que garantisse a subordinação dos nativos fronteiriços em benefício dos desígnios da Coroa espanhola em relação às ricas províncias que se acreditava existiam no interior. A 28 de abril de 1621, o mestiço Diego Ramírez Carlos apareceu em Lima com outro memorial em que fazia constar as exigências dos chunchos: a principal delas, a de não servirem em encomiendas. Afirmava que conseguira trazer a La Paz cinco governadores e 20 principais. $^{87}$

O que Ramírez Carlos não revelou foi sua estratégia de vestir-se de inca e proclamar-se filho de Melchor Carlos Inca, morto no exílio na Espanha. Seu companheiro nessas entradas, o franciscano Gregório de Bolívar, referiu com assombro que o mestiço Ramírez Carlos "se hazia venerar y respetar como mas proximo sucesor del inga" e que, para tanto, tinha por assessor um mulato, a quem mantinha "un clarín tocando por los caminos y entradas de los lugares y chacaras" para que os índios "le saliesen a recebir y venerar como a inga y señor en lo cual gastó más de un año". 88

Pedro Bohorquez utilizou a mesma peculiar estratégia para apresentar-se como um mediador indispensável entre os agentes da colonização e os "índios bárbaros": aparecer como conquistador e como inca. Esperava emitir, assim, uma dupla mensagem, capaz de aderir ao que se esperava tanto na Corte do Peru quanto na fronteira. Para tanto, o suplicante pintou os índios da floresta como possivelmente descendentes dos incas, por serem governados por leis (puniam o adultério, por exemplo), usarem roupas e adornarem-se de pérolas e joias. "Ay señores de provincias tan poderosos y ricos de vassalos" que, inclusive, um deles se dizia senhor geral, a quem todos obedeciam. Assim, em seu informe de 165l, Bohorquez desenhava claramente sua estratégia de utilizar o fato de os índios aceitarem- no como inca ao afirmar que, quando se vestia como eles, era respeitado e obedecido: "trayendo su mesmo traje y vestidura le obedecen q.do les manda con mucho amor, temor y respeto como si fuera su superior". Como era comum nesses memoriais, Bohorquez se apresentava como o único que tinha contato privilegiado com os índios; se as autoridades decidissem por enviar outras pessoas, uma vez que os índios constatassem não estar o suplicante presente, podiam atacar a expedição. ${ }^{89}$

Se havia alguma sutileza na estratégia de Bohorquez, ela consistia em apresentar-se como inca sem reivindicar qualquer direito de ancestralidade, deixando muito claro que o fato de ser visto dessa forma pelos índios era o meio que lhe parecia mais adequado para empreender aquela conquista. Bohorquez apresentava elementos para fazer crer que sua lealdade à monarquia era inabalável e que todo o protocolo tradicional de fundação de cidades fora

que no la darían [la autorización] ni consentirían que entrase en ellos ni otra persona alguna, a menos que fuese viniendo en compañía de su capitán Don Pedro" (AGI. Indiferente General, 631, "Memorial de Pedro Bohorquez", Lima, [1651], f. 2). ${ }^{87}$ AGI. Lima, 151, Memorial de Diego Ramírez de Carlos, 28 abr. 1621.

${ }^{88}$ AGI. Lima, 41, "Relación de la entrada que hizo a las provincias de los Chunchos", 1621 (In: Colección de documentos que apoyan el alegato de Bolivia en el juicio arbitral con la república del Perú, 1906, t. 1, p. 194; cf. também p. 198 e 208).

${ }^{89}$ AGI. Indiferente General, 631, "Memorial de Pedro Bohorquez", Lima, [1651], f. 1v-2. 
seguido. Assim, ao narrar a fundação de San Miguel Arcangel, a 20 de setembro de 1650, aludia que tomara o cuidado de instalar, antes de tudo, o "rollo" ou pelourinho; $;{ }^{90}$ seguiram-se os rituais de posse do território: "descubridores arrancaron yerbas cortaron palos cogieron tierray todo lo echaron al ayre",;1 em seguida, a demarcação dos terrenos para igreja, cabildo e demais casas; ${ }^{92}$ finalmente, os índios, segundo os moldes do requerimiento, juraram, por meio do intérprete, sua obediência ao monarca espanhol. ${ }^{93}$ Apesar de tudo, o relato não deixa de revelar uma tensão importante entre a lealdade monárquica reivindicada e o incomum procedimento do suplicante de entronizar-se como chefe supremo dos caciques nativos, com a criação de toda uma nova hierarquia étnica e política pendente de confirmação real.

Estratégia discursiva recorrente era a de justificar os pedidos de licença e auxílio para a conquista da Amazônia com a sugestão de reorientar a rota de escoamento da prata de Potosí por uma via direta até o Atlântico. Uma das primeiras propostas nesse sentido apareceu pouco antes de 1569, quando o procurador da Audiência de Charcas referiu à Coroa as vantagens de abrir uma rota de navegação entre o Peru e o mar do Norte, por onde era possível conduzir a prata potosina e o comércio com a Espanha. ${ }^{94}$

O açoriano Simão Estácio da Silveira chegou ao Maranhão em 1619, como capitão da nau de Jorge Lemos Bitencourt, acompanhado de 300 pessoas oriundas das ilhas atlânticas, que foram povoar as novas terras amazônicas. Como procurador-geral da câmara de São Luís, empenhou-se em escrever informes e requerimentos à Coroa espanhola (Raminelli, 2006, p. 124). Em uma "Relação sumaria das cousas do Maranhão", de 1624, inventariava as principais riquezas dessa que considerava "a melhor terra do mundo", e o "Brazil melhor, \& mais perto de Portugal", como a fertilidade da terra, as carnes e aves, mariscos e pescados, e, sobretudo, as drogas. ${ }^{95}$ Em "Intentos da jornada do Pará", Silveira (1904, p. 362 e 366) estimava que o rio Marañón era um dos principais afluentes do Amazonas e que nasce "hum pouco ao Norte do serro de Potosí", o qual acreditava ser perto de Cuzco. Amparado nessas fantasiosas noções hidrográficas, esperava explorar o Amazonas a oeste com mais detalhe, a fim de abrir "hua grande porta as riquesas do Perú", por onde descessem à Espanha sem os grandes trabalhos da frota das Índias.

Por fim, em um memorial de 1626, propôs a conquista do Marañón e do Paititi, o envio de colonos dos Açores para a Amazônia e o transporte da prata peruana ao Atlântico pela rota do Amazonas. Neste último papel, efetivamente, o mito do El Dorado era confundido com o do Paititi. Silveira lembrava que Juan Recio de León e seus companheiros, desde o

\footnotetext{
90 Ibidem, f. 4.

${ }^{91}$ Ibidem, f. 4V.

${ }^{92}$ Ibidem, f. $6 \mathrm{~V}$

93 Ibidem, f. 7.

${ }^{94}$ AGl. Charcas, 418, t. 1, f. 174v-175, Real cédula à Audiência de Charcas, Madri, 12 fev. 1569.

95 Biblioteca Nacional de España (BNE), Madri, R/17270 (12), f. 83-94, "Relação sumaria das cousas do Maranhão", Simão Estácio da Silveira, impresso em Lisboa, 1624.
} 
Peru, "han empeçado ya a tocar estas riquezas". Agora, curiosamente, supunha que os "enemigos del Norte", holandeses ou ingleses, tinham um "castillo de importancia en la barra del río Pará, y comerciando con los Gentiles Guarijòos, y otros de la tierra adentro, llegan al Paititi, y empiezan a gozar algunas destas riquezas". Assim, súditos das potências hereges já estariam em contato com índios do próprio Peru, "induziendolos en sus perversas setas", uma imagem que sugere que Silveira partilhava da confusão geográfica comum à época, segundo a qual se podia passar da banda setentrional do rio Amazonas, onde os holandeses realmente atuavam, sem demora, ao piemonte dos Andes peruanos. ${ }^{96}$

\section{O ceticismo do poder central}

Não admira que a recepção desses textos pelo poder central fosse marcada por uma atitude cética dos membros e assessores do Consejo de Indias. As autoridades eram ambíguas: se os intentos fracassavam, ou se alcançavam pobres e efêmeros resultados, os funcionários faziam vistas grossas ou reprimiam eventuais desordens. Se alcançavam algum êxito, logo procuravam apropriar-se dos benefícios e institucionalizar a colonização desde o princípio (Lorandi, 1997, p. 315).

O Consejo de Indias estava tão acostumado a ouvir disparates sobre ricas províncias que se tornou hábil em manipular essas imagens quando lhe convinha. É assim que o novo governador de Santa Cruz de la Sierra, Francisco López Zúñiga, se queixou, em carta de maio de 1635, de haver sido enviado para uma província que aquele tribunal prometera ser rica e abundante em "cerros de plata", quando em realidade só contava uma cidade, 220 colonos mestiços e generalizada pobreza. ${ }^{97}$

Realmente, a exigência de prêmios que o poder central considerava despropositados foi algo recorrente nos memoriais que chegavam a Madri, e uma das principais razões para que as súplicas fossem denegadas. Alonso de Miranda, após realizar uma entrada aos omáguas, em 1621, requereu autorização para fundar cinco cidades; título de marquês; 20 mil ducados de renda; título de fidalgo para si, para os descendentes e para todos os soldados e participantes da expedição que não o tivessem; e competência para repartir solares e terras de cultivo. ${ }^{98}$ Uma real cédula, expedida no mesmo ano, rechaçou o pedido como despropositado e ponderou que o título de marquês nem mesmo existia no vice-reino do Peru, sendo algo alheio à razão introduzi-lo, "pues podría ser que todo el interés de dichos descubrimiento y poblaciones

96 AGI. Lima, 159, Memorial de Simão Estácio da Silveira, Madri, 15 jun. 1626, f. 1-1v.

97 AGI. Lima, 162, “Carta de Francisco López Zúñiga”, 15 maio 1635.

${ }^{98}$ AGl. Quito, 50, n. 32, "Información de Alonso de Miranda, gobernador de Quijos" [Quito, 28 abr. 162O], f. 3 et passim; e AGI. Quito, 50, n. 32, “Carta de la Audiencia de Quito sobre el memorial del gobernador Alonso de Miranda”, 18 abr. 1620. 
no alcanzan para semejantes premios". ${ }^{99} \mathrm{O}$ Consejo de Indias, em uma minuta da real cédula sobre o assunto, chegou a estranhar como "estando tan a los principios se propone una cosa grandiosa". ${ }^{100}$

Eram recorrentes os pedidos de mercês de territórios imensos, que revelavam não apenas as deficientes noções de geografia da época, mas sobretudo o oportunismo político dos interessados. Assim, por exemplo, as terras que Maraver de Silva chamava, em 1568, de Nova Estremadura "se extienden e alcançan", diz o seu memorial, "desde en seis grados a la parte del Sur trezientas leguas de latitud al dicho Sur y otras trezientas de longitud Leste Oeste". Converta-se isso com a medida habitual da antiga légua espanhola e se terá uma área de 2.794 .948 quilômetros quadrados, que abarcava o seguinte: "Parece claro que la liña de Leste Oeste alcança la dicha mi governación a los límites e cordilleras d'estas sierras del Pirú y por la línea del Norte Sur desde el río de Orellana [isto é, o rio Amazonas] hasta espaldas de las Charcas". ${ }^{101}$ Essas quiméricas ideias geográficas podiam ser defendidas com espantosa meticulosidade, como quando o próprio Maraver de Silva protestou que Jímenez de Quesada lhe havia tomado alguns soldados e que sua jurisdição compreendia tanto os omáguas do Peru quanto os omeguas de Nova Granada. ${ }^{102}$ Como observou Juan Gil (1989, t. 3, p. 103), de uma única letra pendiam os direitos sobre imensos e desconhecidos territórios e sobre suas populações. Por outro lado, as próprias autoridades complicavam a situação ao conceder mercês que se sobrepunham: o vice-rei Toledo, por exemplo, malgrado as pretensões de Maraver de Silva, concederia as províncias de Papamene e Omagua ao governador de Quijos, Melchor Vázquez de Avila. ${ }^{103}$ Como quer que seja, a jornada de Malaver de Silva também fracassou pelos rigores do inverno, pela epidemia que grassou sobre a comitiva e pela falta de auxílios da Audiência de Santa Fé..$^{104}$

Também havia quem tentasse assegurar pretensões territoriais por meio do acréscimo de nomes de etnias, províncias, rios, lagos e outros acidentes geográficos aos títulos de governações acertados com as autoridades. Em alguns casos, as manipulações começavam

\footnotetext{
${ }_{99}$ AGI. Quito, 88, n. 38, "Informaciones", f. 10v-11, real cédula à Audiência de Quito, Madri, 7 jun. 1621, f. 11. Curiosamente, o poder central omite a concessão do marquesado de Santiago de Oropesa, feita em 1614, ao casal Ana María Coya de Loyola, filha de um conquistador do Peru e de uma princesa inca, e Juan Enríquez de Borja. Com ampla jurisdição sobre o vale de Yucay, próximo a Cuzco, o título dividiu opiniões em Lima: uns alertavam para os riscos de um levante incaico, outros reclamavam mercês similares. Os marqueses retornaram a Madri, após residirem por pouco mais de uma década no Peru (Lohmann Villena, 1948-1949, p. 430-436).

100 AGI. Quito, 50, n. 32, Minuta de real cédula à Audiência de Quito, Madri, 28 mar. 1621. Outros exemplos de pedidos de premiações exorbitantes incluem o memorial de Gonzalo Rodríguez de Monroy, em que pedia que suas futuras concessões de encomiendas não passassem pelo Consejo de Indias, e o de Juan Bautista Sánchez de Orellana, que pretendia nada menos que a presidência da Audiência de Quito. Ambos se dirigiam à conquista dos jívaros. O primeiro foi obrigado a retirar o ponto sobre as concessões e acabou bloqueado pela petição de outro interessado. O segundo, na opinião do fiscal, não contava com as qualidades necessárias para o que pretendia (cf. respectivamente: "Capitulaciones" e Parecer do Fiscal, Quito, 21 jan. 1651; Petição de Pedro Vaca de la Cadena, Los Reyes, 9 out. 1653, In: Revista de Archivos y Bibliotecas Nacionales, 1899, p. 249-255, 265 et seq.; AGI. Quito, 143, n. 20, "Memorial de Juan Bautista Sánchez de Orellana", 29 fev. 1720, f. 292-292v; e Parecer do Fiscal, Madri, 29 fev. 1720)

${ }_{101}$ AGI. Patronato, 154, n 3, r. 3, f. 14-14v, Memorial de Pedro Maraver de Silva, 1570.

102 AGI. Patronato, 154, n 3, r. 3, f. 31 et seq.. Informação realizada em Chachapoyas, 4 mar. 1572.

${ }^{103}$ AGI. Lima, 28-B, liv. 4, f. 21v, Carta de 10 mar. 1572.

${ }^{104}$ AGI. Patronato, 154, n. 3, r. 3, Informação, 1572, f. 13, 31.
} 
na própria apresentação do memorial, quando o acréscimo da ilha de Margarita, dos omáguas (ou omeguas) ou de outra paragem ou etnônimo, conforme fosse o caso, já servia para dilatar as futuras jurisdições por muitas léguas a leste. ${ }^{105}$ Outros, como Martín de la Riva Herrera, de forma sub-reptícia, apareciam com uma lista cada vez maior de grupos indígenas atrelados às suas governações. ${ }^{106}$

O ceticismo, aliás, parece não ter contagiado todos os funcionários coloniais. Quando a Audiência de Charcas reuniu, em 1644, numerosos testemunhos dos "capitães de Paititi" para informar o memorial de Francisco Rodriguez Peinado, colono de Santa Cruz de la Sierra, notícias como a da província de prateiros e a da lagoa onde o Sol se punha chegaram a atrair o fiscal Fabián de Valdés Carrillo. Sua única ressalva era a de que o chefe da expedição não fosse Peinado, mas o presidente de La Plata. ${ }^{107}$ No que não aderiu o vice-rei conde de Chinchón, ${ }^{108}$ para quem tais notícias, como outras do mesmo teor, não correspondiam à realidade; animavam entradas que eram custosas; e que só serviam para irritar os índios de guerra e molestar os de paz. ${ }^{109}$

Em todo caso, as incoerências da geografia fantástica que orientava os memoriais eram percebidas pelos funcionários reais. Uma reavaliação das notícias de El Dorado foi feita pelo vice-rei Francisco de Toledo em 1572. Em realidade, em uma carta anterior, de 25 de março de 1571, Toledo pensava que a notícia de que o Paititi estava em Mojos era a mais interessante: "de más aprovada noticia y de mayor riqueza que ay en las que agora se saven". ${ }^{110}$ Contudo, na carta de lo de março de 1572, o vice-rei colocava o Mojos e o Paititi entre as províncias ilusórias e infrutuosas pelo "grande gasto y poco provecho que resulta a la corona Real". 111

\footnotetext{
105 Alvaro Enríquez del Castillo, morador de Chachapoyas, que inicialmente divulgara a necessidade de reduzir os motilones e os tabalosos, apareceu em 1612 com um memorial em que assegurava poder conquistar todos os demais índios que habitavam as ribeiras do rio Marañón até a ilha de Margarita e o Brasil. Catorze sacerdotes e 150 vecinos casados eram suficientes, em seu entender, para salvar das garras do demônio mais de 800 mil índios. Ora, chama atenção a imprecisão do governo que pedia, pois a ilha de Margarita está ao norte da foz do rio Orinoco e bem longe da costa do Brasil, se se entende por esta última a foz do rio Amazonas. (AGl. Lima, 141, "Relación y apuntamientos d'estos recaudos que se trata de sobre la jornada de los motilones y el río Marañón” [c. 1612]). Ao que se sabe, o vice-rei Montesclaros rechaçou o projeto por ter sob sua proteção outro caudilho (AGI. Lima, 36, v. 6, f. 104, Carta de 11 abr. 1612). 106 O referido colono conseguira capitular a conquista e a pacificação dos motilones, tabalosos, pabalosos, casas blancas e omagos (real cédula ao vice-rei do Peru, Madri, 17 abr. 1650, In: Revista de Archivos y Bibliotecas Nacionales, 1899, p. 43-49). Em uma carta de 12 de maio de 1655, incluiu entre os grupos que governava os jibitos, cholones, juanuncos, cascabosoas, payananços, cocamas, aguanos, otanavis e motilones. Lista engrossada em 21 de maio de 1657, quando fez constar os nomes dos pavalosos, miliquines, ruamainas, conchas, abitoas, coronatoas, atios e coronados (AGl. Lima, 169, cartas de Riva Herrera, 12 maio 1655 e 21 maio 1657). Em outro informe deste último ano, estavam agregados à lista de grupos supostamente reduzidos os tavalosos, ebolones e barbudos (AGI. Lima, 169, Informe de Martín de la Riva Herrera, Cajamarca, 21 abr. 1657, f. 1).

${ }_{107}$ AGl. Charcas, 90, Parecer de Fabián de Valdés Carrillo, 26 fev. 1644.

108 AGl. Charcas, 90, Carta do vice-rei conde de Chinchón, 16 ago. 1647.

109 AGI. Lima, 49, v. 1, ano de 1639, Carta do vice-rei conde de Chinchón, 20 jan. 1639, f. 33 et seq.

${ }^{110}$ AGI. Lima, 28-A, n. 49, Carta de Francisco de Toledo ao rei, 25 mar. 1571, f. 22v, § 23.

III AGI. Lima, 28-B, f. 19 et seq.. "Carta del virrey don Francisco de Toledo a S.M.", Cuzco, 10 mar. 1572 (In: Levillier, 1924, t. 4, Carta, p. 48-208, Sumário, p. 209-251, cit. p. 218, ver também p. 88)
} 
A opinião que predominava entre os funcionários reais era a de que as expedições eram conduzidas por homens sem recursos e violentos, que, além de não cuidarem de evangelizar índio algum (antes inquietavam aqueles que encontravam), causavam toda sorte de problemas nas cidades, onde reuniam suas tropas entre a gente pobre e sensível às suas promessas vazias. Tal era o parecer do fiscal Nicolás Polanco de Santillana em um informe de 1663, em que chegou a definir como "facinorosos" aqueles que se dedicavam a apresentar memoriais sobre conquistas de El Dorado e Paititi. Polanco de Santillana, em realidade, tinha em mente o caso concreto dos serviços alegados por Martín de la Riva Herrera, que, durante a década anterior, teria realizado expedições nas regiões de Jívaros e Maynas. O fiscal considerava justo o pleito que corria para que esse "conquistador" pagasse os 30 mil ducados de fiança estabelecidos em suas capitulações, caso não realizasse o que prometera. Na opinião de Polanco, os memoriais denotavam um grave problema social. As conquistas alegadas eram "de nombre y de ninguna utilidad", feitas por pessoas pobres e que apenas davam mau exemplo aos índios. Afirmava, ainda, que havia poucos eclesiásticos e que, de resto, os índios tomavam ódio pela religião católica; e que não havia dinheiro nem mesmo para o já conquistado, quanto mais para terras por conquistar. Terras sem riqueza e sem comércio, das quais não se podiam esperar recursos que as pudessem manter: a própria conquista do Paititi era um exemplo disso, de modo que o fiscal havia rechaçado os últimos pedidos para ir a ela e todos os memoriais que solicitavam licença para entradas semelhantes. Sendo muita a pretensão desses "hombres pobres, y sin caudal heredado ni propio", "sin gente ni armas", afirmar que, porque os índios toleram a presença de um religioso devoto que estava disposto a ser mártir, já haviam se convertido, e com isso pretendiam grandes prêmios da Coroa. ${ }^{112}$ Finalmente, entendia que as alegadas novas conquistas não facultavam rendimento algum, antes ocasionavam despesas para as quais não alcançavam as rendas da Real Fazenda. ${ }^{113} \mathrm{O}$ Consejo de Indias concluiu suas deliberações sobre o assunto em 23 de julho de 1664 e, dando mostras de concordar com Polanco, recomendou que as autoridades do vice-reinado não inovassem em coisa alguma quanto ao tema das entradas sem que fossem realizadas as consultas suficientes. ${ }^{114}$

Os memoriais de Recio de León, observa o historiador Glave Testino (1993, p. 11), aparecem em um contexto de "aumento de la gente española suelta en los caminos y pueblos" em tensa vizinhança com os índios fronteiriços, época em que a economia mostrava sinais de esgotamento e a cena política da Corte do vice-reinado era agitada por conflitos entre toda sorte de facções. "Reduzir" toda essa gente em novas cidades a serem estabelecidas na floresta era uma meta perseguida por Recio e por outros suplicantes. Se é certo que, aos olhos das autoridades coloniais, se tornava cada vez mais comum a "desclassificação" dos que propunham ou participavam das expedições às regiões interiores, a retórica negativa tinha por

\footnotetext{
112 AGI. Lima, 102, “El fiscal Nicolás Polanco de Santillana”, Lima, 31 jul. 1663, f. 2-2v.

${ }^{113}$ Ibidem, f. $5 \mathrm{~V}$

114 Ibidem, f. [s.n.]: Despacho do Consejo de Indias, 24 jul. 1664.
} 
base a difícil situação experimentada por boa parte dos colonos do Peru. Efetivamente, pela década de 1620, "se hicieron realidad las advertencias sobre el peligro que significaba el crecimiento de gente suelta, sin ubicación en el tejido social que se transformaba".

\section{Considerações finais}

Se havia alguma predisposição mítica entre colonos, missionários e autoridades coloniais que permitisse que imagens de populações e países fantásticos circulassem na documentação oficial, o certo é que ela era manipulada, por razões políticas, tanto por setores locais quanto pelo poder central. Nesse sentido, ainda que se possa considerar que os próprios nativos pudessem fornecer informações sobre eventuais riquezas minerais existentes em determinada paragem, ou sobre grupos indígenas escondidos nas regiões interiores, essas notícias eram reinterpretadas por colonos e missionários, de modo a servir a seus projetos de obtenção de jurisdição sobre territórios, encomiendas e recursos para missões religiosas.

Do mesmo modo, as descrições que os que escreviam memoriais faziam dos índios fronteiriços e da paisagem das terras baixas amazônicas passavam necessariamente pelo filtro da comunicação política com o poder central. Colonos e funcionários podiam manipular imagens fantásticas com vistas atrair a atenção e o apoio de credores e de autoridades a seus projetos políticos. Também as ordens religiosas podiam manipular essas imagens, de modo a atrair o apoio da Coroa para o financiamento de missões aos "infiéis".

A proliferação de memoriais que solicitavam licença para conquistar países imaginários revelava um enorme problema social no vice-reinado do Peru. O número de espanhóis e mestiços pobres, desprovidos de encomiendas, e que buscavam encontrar um lugar para si já orçava pela metade da população não indígena nos Andes centrais, nas últimas décadas do século XVI, e a situação não melhorou no início do século seguinte.

Nesse quadro, as atitudes do poder central foram marcadas pelo ceticismo, o que evidencia que a predisposição mítica dos funcionários reais era muito menor do que os suplicantes esperavam. O poder central apoiava expedições até o momento em que elas conviessem a seus desígnios. Quando os prêmios solicitados eram considerados exorbitantes; ou quando as estratégias dos aventureiros parecia fugir do controle (ao apelar para projetos neoincaicos, por exemplo), então era o momento de denegar novas licenças, de não pagar os prêmios prometidos ou mesmo de encarcerar os suplicantes.

Mas o poder central nunca chegou a reprimir a proliferação desses memoriais, antes parecia incentivá-la, esperando que a competição entre os atores locais favorecesse não apenas a produção de informações sobre as regiões distantes, mas a consolidação da soberania territorial espanhola nelas. Ao mesmo tempo, ainda que reconhecesse que as 
entradas podiam gerar novos distúrbios (como o abandono das cidades já fundadas ou o desenvolvimento de um sentimento de hostilidade aos espanhóis entre os grupos indígenas fronteiriços, contatados por expedicionários interessados em reuni-los em encomiendas), o poder central não podia simplesmente fechar essa válvula de escape para os problemas sociais do vice-reinado, oriundos de uma massa de colonos desprovidos de qualquer função estável naquela sociedade.

A explicação para esse fenômeno se encontra na própria natureza da comunicação política entre os súditos e o poder central, a qual orientava o funcionamento dessas expedições. Malgrado colonos e missionários não raro realizassem, inicialmente, algumas entradas às terras baixas sem licença, em algum momento eles precisavam solicitá-la, pois somente assim podiam aceder às mercês e honras prometidas aos que realizavam esses serviços e aos recursos que a monarquia comumente fornecia às missões entre os índios de fronteira. Assim, uma vez que essas expedições iam para o papel sob a forma de memoriais e informações de serviço, as forças centrífugas que as impulsionavam iniciavam um movimento contrário, agora centrípeto, e a desobediência passava a ser retratada como serviço leal e imprescindível à monarquia.

Os memoriais evidenciam, portanto, uma enorme capacidade do poder central de controlar as periferias, não por via do monopólio da força (que em realidade não tinha), mas pela rede de informação que promovia, ao contar com observadores e atores que sempre deviam reportar suas ações e as dos outros a Madri. A Corte continuava a ser não somente um espaço de processamento e acumulação da informação, mas sobretudo um núcleo definidor da honra e da qualidade de cada súdito, a que todos deviam acudir para prestar contas de seus serviços e receber as premiações almejadas. 


\section{Referências bibliográficas}

ACUÑA, Cristóbal de, S.J. Nuevo descubrimiento del Gran Río de las Amazonas. Madri: Iberoamericana, 2009 [1641].

AMICH, José, O.F.M. Historia de las misiones del Convento de Santa Rosa de Ocopa. Iquitos, Peru: Ceta/IIAP, 1988 [1771].

BAYLE, Constantino, S.J. El Dorado fantasma. 2. ed. Madri: Consejo de la Hispanidad, 1943.

BLOCK, David. Mission culture on the Upper Amazon: native tradition, Jesuit enterprise, and secular policy in Moxos, 1660-1880. Lincoln: University of Nebraska Press, 1994.

BRENDECKE, Arndt. Imperio e información: funciones del saber en el dominio colonial español. Madri: Iberoamericana, 2012.

CARDOSO, Alírio. Maranhão na monarquia hispânica: intercâmbios, guerra e navegação nas fronteiras das Índias de Castela (1580-1655). Tese (Doutorado), Universidad de Salamanca, Salamanca, 2012.

CHAMBOULEYRON, Rafael. Opulência e miséria na Amazônia seiscentista. Raízes da Amazônia, v. l, n. 1, p. 105-124, 2005.

CHUCHIAK, John F. Toward a regional definition of idolatry: reexamining idolatry trials in the "relaciónes de méritos" and their role in defining the concept of "idolatria" in colonial Yucatán, 1570-1780. Journal of Early Modern History, v. 6, n. 2, p. 140-167, 2002.

COLECCIÓN de documentos que apoyan el alegato de Bolivia en el juicio arbitral con la república del Perú. Buenos Aires: Compañía Sud-Americana de Billetes de Banco, 1906. t. 1.

COMBÈS, Isabelle. El Paititi y las migraciones guaraníes. In: TYULENEVA, Vera (Ed.). Paititi: ensayos y documentos. Cochabamba: Instituto de Misionología, 2011. p. 52-98.

ELLIOTT, John H. Philip IV of Spain: prisoner of ceremony. In: DICKENS, A. G. (Ed.). The courts of Europe: politics, patronage, and royalty 1400-1800. Nova Iorque: McGraw-Hill, 1977. p. 169-189.

ESPINOZA SORIANO, Waldemar. Amazonía del Perú: historia de la gobernación y comandancia general de Maynas. Lima: Fondo Editorial del Congreso del Perú, 2007.
FERNÁNDEZ DE OVIEDO Y VALDÉS, Gonzalo. Historia general y natural de las Indias. Madri: Imprenta de la Real Academia de la Historia, 1855 [1548]. Tercera parte, t. 4

FINOT, Enrique. Historia de la conquista del oriente boliviano. Buenos Aires: Librería Cervantes, 1939.

FOLGER, Robert. Writing as poaching: interpellation and self-fashioning in colonial relaciones de méritos y servicios. Leiden/Boston: Brill, 2011.

GANDÍA, Enrique de. Historia crítica de los mitos y leyendas de la conquista americana. Buenos Aires: Centro Difusor del Libro, 1946.

GARCÍA BERNAL, Manuela Cristina. La encomienda: voluntad legal y realidad yucateca. Temas Americanistas, n. 7, p. 73-88, 1990.

GARCÍA RECIO, José María. Análisis de una sociedad de frontera: Santa Cruz de la Sierra en los siglos XVI y XVII. Sevilha: Diputación Provincial de Sevilla, 1988.

GIL, Juan. Mitos y utopías del descubrimiento: El Dorado. Madri: Alianza, 1989. t. 3.

GLAVE TESTINO, Luis Miguel. De rosa y espinas: creación de mentalidades criollas en los Andes (16001630). Lima: IEP, 1993.

Fray Alonso Granero de Ávalos y los naturales andinos: debates sobre el destino de la sociedad colonial a inicios del siglo XVII. Cuadernos Interculturales, Viña del Mar, Chile, v. 5, n. 8, p. 15-50, 2007.

GÓMEZ GONZÁLEZ, Juan Sebastián. Frontera selvática: españoles, portugueses y su disputa por el noroccidente amazónico, siglo XVIII. Bogotá: Instituto Colombiano de Antropología e Historia, 2014.

HEMMING, John. The search for ElDorado. Nova Iorque: Dutton, 1979.

HOLANDA, Sérgio Buarque de. Visão do paraíso: os motivos edênicos no descobrimento e colonização do Brasil. São Paulo: Brasiliense, 2000.

IBÁÑEZ BONILLO, Pablo. El martirio de Laureano Ibáñez: guerra y religión en Apolobamba, siglo XVII. La Paz: Foro Boliviano sobre Medio Ambiente y Desarrollo, 2011.

JOUANEN, José, S.J. Historia de la Compañía de Jesús en la antigua provincia de Quito: 1570-1773. Quito: Ecuatoriana, 1941, v. 1; 1943, v. 2. 
LANE, Kris E. Quito 1599: city and colony in transition. Albuquerque: University of New Mexico Press, 2002.

LATOUR, Bruno. Science in action: how to follow scientists and engineers through society. Cambridge, Mass.: Harvard University Press, 1987.

LEÓN PINELO, Antonio de. El paraíso en el Nuevo Mundo: comentario apologético, historia natural y peregrina de las Indias Occidentales islas de tierra firme del Mar Occeano. Lima: Imprenta Torres Aguirre, 1943 (ed. de Raúl Porras Barrenechea) [1656]. 2 t.

LEVILLIER, Roberto. El Paititi, el Dorado y las Amazonas. Buenos Aires: Emecé, 1976.

(Ed.). Gobernantes del Perú: cartas y papeles, siglo XVI: documentos del Archivo de Indias. Madri: Sucesores de Rivadeneyra, 1921. t. 1.

(Ed.). Gobernantes del Perú: cartas y papeles, siglo XVI: documentos del Archivo de Indias. Madri: Imprenta de Juan Pueyo, 1924. t. 4.

LIVI BACCI, Massimo. El Dorado en el pantano: oro, esclavos y almas entre los Andes y la Amazonia. Madri: Marcial Pons, 2012.

LOCKHART, James. El mundo hispanoperuano, 15321560. México: 1982.

LOHMANN VILLENA, Guillermo. El señorío de los marqueses de Santiago de Oropesa en el Perú. Anuario de Historia del Derecho Español, Madri, v. 19, p. 347-458, 1948-1949.

LORANDI, Ana María. De quimeras, rebeliones y utopías: la gesta del inca Pedro Bohorques. Lima: Pontificia Universidad Católica del Perú, 1997.

Identidades ambiguas: movilidad social y conflictos en los Andes, siglo XVII. Revista de Indias, v. 57, n. 1, p. 111-135, 2000.

MACLEOD, Murdo J. Self-promotion: the relaciones de méritos y servicios and their historical and political interpretation. Colonial Latin American Historical Review, Albuquerque, v. 7, n. 1, p. 25-42, 1998.

MALDAVSKY, Aliocha. Vocaciones inciertas: misión y misioneros en la provincia jesuita del Perú en los siglos XVI y XVII. Sevilha: CSIC, 2012.

MARAVALL, José Antonio. La cultura del barroco: análisis de una estructura histórica. Barcelona: Ariel, 2012. MAURTUA, Víctor M. (Ed.). Juicio de límites entre el Perú y Bolivia: prueba peruana. Barcelona: Henrich y Comp., 1906. t. 9.
MEDINA ROJAS, Francisco de Borja, S.J. ¿Exploradores o evangelizadores? La misión de los Mojos: cambio y continuidad (1667-1676). In: HERNÁNDEZ PALOMO, José Jesús; MORENO JERIA, Rodrigo (Ed.). La misión y los jesuitas en la América Española, 1566-1767: cambios y permanencias. Sevilha: CSIC, 2005. p. 187-230.

NEWSON, Linda A. Life and death in early colonial Ecuador. Norma: University of Oklahoma Press, 1995.

Between Orellana and Acuña: a lost century in the history of the north-west Amazon. Bulletin de l'Institut Français d'Etudes Andines, v. 25, n. 2, p. 203-231, 1996.

OBEREM, Udo. Los Quijos: historia de la transculturación de un grupo indígena en el Oriente Ecuatoriano. Otavalo, Ecuador: Instituto Otavaleño de Antropología, 1980.

RAMINELLI, Ronald. Serviços e mercês de vassalos da América Portuguesa. Historia y Sociedad, Medellín, v. 12, p. 107-131, 2006.

RAMOS, Gabriela. Política eclesiástica y extirpación de idolatrías: discursos y silencios en torno al Taqui Onqoy. In: ___ _ URBANO, Henrique (Ed.). Catolicismo y extirpación de idolatrías, siglos XVI-XVIII. Cuzco: Centro de Estudios Regionales Andinos "Bartolomé de las Casas", 1993. p. 137-168.

RAMOS PÉREZ, Demetrio. El mito del Dorado: su génesis y processo. Caracas: Academia Nacional de la Historia, 1973.

REGALADO DE HURTADO, Liliana. Improntas socioeconómicas en la evangelización de Vilcabamba. Histórica, Lima, v. 15, n. 2, p. 315-335, 1991.

RELACIONES geográficas de Indias (RGI). Perú. Madri: Tip. de Manuel G. Hernández, 1885. t. 2.

Perú. Madri: Tip. de los Hijos de M. G. Hernández, 1897. t. 4.

RENARD-CASEVITZ, France M. et al. Al este de los Andes: relaciones entre las sociedades amazónicas y andinas entre los siglos XV y XVII. Quito: AbyaYala, 1988.

REVISTA de Archivos y Bibliotecas Nacionales, Lima, ano 2, v. 3, 1899.

RUMAZO GONZÁLEZ, José. La región amazónica del Ecuador en el siglo XVI. Sevilha: Escuela de Estudios Hispano-Americanos, 1946.

SAEGER, James Schofield. Survival and abolition: the eighteenth century Paraguayan encomienda. The Americas, v. 38, n. 1, p. 59-85, 1981. 
SAIGNES, Thierry. Los Andes orientales: historia de un olvido. Lima: Instituto Francés de Estudios Andinos, 1985.

; BOUYSSE-CASSAGNE, Therese. Dos confundidas identidades: mestizos y criollos en el siglo XVII. Senri Ethnological Studies, Osaka, v. 33, p. 14-26, 1992.

SANCHEZ, Jean-Pierre. Mythes et légendes de la conquête de l'Amérique. Rennes: Presses Universitaires de Rennes, 1996. 2 v.

SCOTT, Heidi V. Contested territory: mapping Peru in the sixteenth and seventeenth centuries. Notre Dame, Ind.: University of Notre Dame Press, 2009.

SEED, Patricia. Ceremonies of possession in Europe's conquest of the New World, 1492-1640. Cambridge: Cambridge University Press, 1995.

SILVEIRA, Simão Estácio da. Intentos da jornada do Pará. Anais da Biblioteca Nacional, Rio de Janeiro, v. 26, p. 361-366, 1904.
SIMÓN, Pedro, O.F.M. Noticias historiales de las conquistas de Tierra Firme en las Indias Occidentales: "tercera noticia”. Bogotá: Medardo Rivas, 1891 [c. 1627]. v. 2, segunda parte.

TOMICHÁ CHARUPÁ, Roberto. La primera evangelización en las reducciones de Chiquitos, Bolivia (1691-1767): protagonistas y metodología misional. Cochabamba: Verbo Divino, 2002.

UGARTE, Auxiliomar Silva. Sertões de bárbaros: o mundo natural e as sociedades indígenas da Amazônia na visão dos cronistas ibéricos (séculos XVI-XVII). Manaus: Valer, 2009.

VEGA, Garcilaso de la. Comentarios reales de los incas. Caracas: Ayacucho, 1991 [1609]. 2 v.

VITAR, Beatriz. Guerray misiones en la frontera chaqueña del Tucumán (1700-1767). Madri: CSIC, 1997.

ZAVALA, Silvio A. Las instituciones jurídicas en la conquista de América. 3. ed. México: Porrúa, 1988. 